\title{
Sediment ANd Nutrient Modeling For TMDL DEVELOPMENT AND IMPLEMENTATION
}

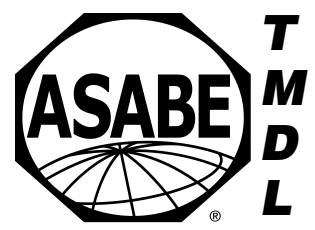

\author{
D. K. Borah, G. Yagow, A. Saleh, P. L. Barnes, W. Rosenthal, E. C. Krug, L. M. Hauck
}

\begin{abstract}
At present, there are over 34,000 impaired waters and over 58,000 associated impairments officially listed in the U.S. Nutrients and sediment are two of the most common pollutants included in the list. States are required to identify and list those waters within their boundaries that are not meeting standards, to prioritize them, and to develop Total Maximum Daily Loads (TMDLs) for the pollutants of concern. Models are used to support development of TMDLs, typically to estimate source loading inputs, evaluate receiving water quality, and determine source load allocations so that receiving water quality standards are met. Numerous models are available today, and selection of the most suitable model for a specific TMDL project can be daunting. This article presents a critical review of models simulating sediment and nutrients in watersheds and receiving waters that have potential for use with TMDL development and implementation. The water quality models discussed, especially those with sediment and/or nutrient components, include loading models (GWLF and PLOAD), receiving water models (AQUATOX, BATHTUB, CE-QUAL-W2, QUAL2E, and QUAL2K), and watershed models having both loading and receiving components (AGNPS, AnnAGNPS, CASC2D/GSSHA, DWSM, HSPF, KINEROS2, LSPC, MIKE $S H E$, and SWAT). Additional models mentioned include another receiving water quality model (WASP), watershed models (ANSWERS storm event, ANSWERS continuous, PRMS storm event, SWMM, and WEPP), and BMP models (APEX, REMM, and VFSMOD). Model sources, structures, and procedures for simulating hydrology, sediment, and nutrients are briefly described for the reviewed models along with an assessment of their strengths, limitations, robustness, and potentials for using in sediment and/or nutrient TMDLs. Applications of AGNPS, APEX, BATHTUB, CE-QUAL-W2, GWLF, and SWAT in TMDL developments are presented. Applications of some of the other models (DWSM, GSSHA, and KINEROS2) relevant to TMDL studies are also presented. The models proved to be useful; however, they require a learning process. Simple models are easy to use but have limitations; comprehensive models are labor and data intensive but offer extensive analysis tools. Finally, recommendations are offered for advancing the sediment and nutrient modeling technologies as applied to TMDL development and implementation. Advances could be made towards: making the best use of existing models, enhancing the existing models, combining strengths of existing models, developing new models or supplemental components with physically based robust routines, numerous field applications, sensitivity analyses, full documentation, and rigorous education and training.
\end{abstract} Keywords. BMP, Hydrology, Loading, Modeling, Nutrients, Receiving water, Sediment, TMDL, Water quality, Watershed.

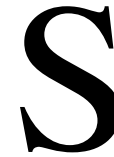
ection 303(d) of the Clean Water Act and the U.S. Environmental Protection Agency's (USEPA) Water Quality Planning and Management Regulations (40 Code of Federal Regulations Part 130) require states to identify and list those waters within their boundaries

Submitted for review in February 2006 as manuscript number SW 6355; approved for publication by the Soil \& Water Division of ASABE in April 2006.

The authors are Deva K. Borah, ASABE Member Engineer, Principal Modeler, Borah Hydro-Environmental Modeling, Champaign, Illinois; Gene Yagow, ASABE Member Engineer, Research Scientist, Virginia Tech, Blacksburg, Virginia; Ali Saleh, ASABE Member Engineer, Research Scientist, Tarleton State University, Stephenville, Texas; Philip L. Barnes, ASABE Member Engineer, Research Engineer, Kansas State University, Manhattan, Kansas; Wesley Rosenthal, ASABE Member Engineer, Associate Professor, Texas A\&M University, Texas Agricultural Experiment Station, Temple, Texas; Edward C. Krug, Biogeochemist, Borah Hydro-Environmental Modeling, Champaign, Illinois; and Larry M. Hauck, Deputy Director, Texas Institute for Applied Environmental Research (TIAER), Tarleton State University, Stephenville, Texas. Corresponding author: Deva K. Borah, Illinois State Water Survey, 2204 Griffith Dr., Champaign, IL 61820; phone: 217-244-8856; fax: 217-333-2304; e-mail: borah@uiuc.edu. that are water quality limited, to prioritize them, and to develop Total Maximum Daily Loads (TMDLs) for the pollutants of concern. Based on most recent state 303(d) lists, there are over 34,000 impaired waters and over 58,000 associated impairments in the U.S. (USEPA, 2006). Metals, pathogens, nutrients, and sediment are the most common pollutants included in the list. Nutrients are the third leading listed cause of water quality impairments, representing $9 \%$ of all impaired segments. Sediment ranks fourth, representing $8 \%$ of all impaired water bodies in the U.S. Sediment is listed for its physical impairment to aquatic habitats, whereas nutrients are listed for impairment by organic enrichment, i.e., through excessive algal growth, which can lead to depletion of dissolved oxygen, among other problems. Additionally, several nitrogen $(\mathrm{N})$ species have detrimental impacts on water quality: ammonia is toxic to fish, and high levels of nitrates cause methemoglobenemia in infants.

A TMDL is the allowable load (amount) of any pollutant that a stream can receive and still meet applicable water quality standards and support its designated use(s). A TMDL is comprised of loads from permitted point, diffused (nonpoint), and natural background sources (Shoemaker et al., 2005). TMDLs must be calculated with seasonal 
variations, account for critical conditions related to stream flow, loading, and water quality parameters, and incorporate a margin of safety, which represents uncertainty in the modeling process (see companion article Shirmohammadi et al., 2006).

Models are used to support development of TMDLs, typically to estimate source loading inputs, evaluate receiving water quality, and determine load allocation to sources so that receiving water quality standards are met. The models help users to understand the dynamics of physical watershed systems that include sources of water and pollutant, and the receiving waters such as lakes, rivers, estuaries, and coastal areas. Models can also answer questions, such as: how do inputs from human sources and land management activities affect loadings to the receiving waters and their conditions, and how should these inputs be changed to improve the conditions? Development of models that can reliably represent the physical systems is challenging. Numerous models are available today, and many of them have been used in environmental and water quality management since the 1970s. However, not all models are appropriate for TMDLs. A model must be capable of quantifying the potential response of the selected endpoints to changes in source pollution loadings. Physically based models are the best suited models.

Shoemaker et al. (2005) conducted an extensive review of existing models and described their various characteristics and capabilities. Some of those models are currently being used for TMDLs, and others have potentials for use in TMDL development. Detailed descriptions of many of the models may be found in Singh (1995) and Singh and Frevert (2002a, 2002b, 2006). Kalin and Hantush (2003) also conducted reviews of many of the models, applied two of the watershed models to an experimental watershed, and evaluated their performances. Borah and Bera (2003) critically reviewed the mathematical bases of eleven leading watershed-scale models and categorized the models by their capabilities, specifically identifying their computational efficiencies and long-term continuous and storm event simulation capabilities. In another study, Borah and Bera (2004) reviewed twelve to eighteen applications of each of three watershed models and discussed their performance abilities. Numerous other applications of the models, especially a few leading ones, may be found in the literature, some comparing relative performances (e.g., Saleh and Du, 2004). Selection of the most suitable model for a particular TMDL project is still a challenging task.

The primary objectives of this article are to conduct a critical review of models simulating sediment and nutrient generations and transport (distribution) that have already been used or have potential for use in TMDL development and implementation; categorize the models into loading models, receiving water models, and watershed models; describe briefly their modeling procedures for simulating hydrology (basic to sediment and nutrient simulations), sediment, and nutrients along with an assessment of their strengths, limitations, robustness, and potentials for use in sediment and/or nutrient TMDLs; review applications of some of the models in TMDL and related studies along with an assessment of their performances, suitability, and shortcomings; and finally, discuss advancing hydrology, sediment, and nutrient modeling technologies with the mention of a few ongoing efforts. Unlike the previous reviews mentioned above, this review focuses on models for sediment and nutrient TMDLs and their distinct categories, strengths, limitations, robustness (computational efficiencies), and other insightful information not commonly available to help in the selection of the most suitable model for a sediment and/or nutrient TMDL. The discussion on advancing modeling technology is another unique feature of this article.

This article is part of a special ASABE TMDL modeling collection effort. The purpose and overview of this collection is outlined in a companion article (Muñoz-Carpena et al., 2006). Five other related topics are discussed in five companion articles, including pathogens (Benham et al., 2006), dissolved oxygen (DO) (Vellidis et al., 2006), biological indicators (Yagow et al., 2006), uncertainty in models (Shirmohammadi et al., 2006), and economics (Bosch et al., 2006). The materials presented here are based on information available in the literature and may not always be from the original sources.

\section{Sediment And Nutrient Models}

The common model characteristics currently needed for TMDL development include: (1) watershed-based, (2) allow for continuous simulation, (3) consider both point and nonpoint pollutants, (4) consider contributions from both surface and groundwater, (5) consider pollutants in both dissolved and particulate phases, where appropriate, and (6) have the ability to represent the major important watershed and land use characteristics influencing the pollutant of concern. In general, suitable models will still differ in their degree of representation of various watershed processes, their need for calibration, their ability to represent spatial and temporal variability throughout the watershed, and in the level of user support available.

USEPA has recognized the importance of modeling for development of TMDLs and has supported the development of a Geographic Information System (GIS) based user interface called BASINS (Better Assessment Science Integrating Point and Nonpoint Sources; USEPA, 2001). This interface serves as a gateway for estimation of parameter values and model input formatting for the following models: AQUATOX, HSPF, PLOAD, QUAL2E, and SWAT. However, because of considerable variability from state to state in standards, data availability, and user preference, these models may not always be the most appropriate for use in a given impaired water body, and therefore are not the only ones used and accepted by USEPA for TMDL development. Some of the other models currently in use include AGNPS, AnnAGNPS, BATHTUB, CE-QUAL-W2, GWLF, and LSPC (an enhanced version of HSPF).

These models can be categorized into three general classes for TMDL development: (1) loading models, (2) receiving water models, and (3) watershed models. GWLF and PLOAD are loading models that estimate loadings of water, sediment, and/or chemicals from a watershed outlet into a water body. AQUATOX, BATHTUB, CE-QUAL-W2, and QUAL2E are receiving water models that analyze water quantity and/or quality in a receiving water body (stream, impoundment, lake, estuary, etc.) in response to loadings from its contributing watershed(s). Watershed models, such as AGNPS, AnnAGNPS, HSPF, LSPC, and SWAT, have capabilities of both the loading models and some capabilities 
of the receiving water models because they estimate water, sediment, and chemical loadings from different parts of a watershed into its streams and/or lakes and analyze water quantities and/or qualities of the receiving waters as well.

Watershed models can be further subdivided into two distinct categories: (1) long-term continuous models (simply referred to as continuous watershed models), and (2) storm event watershed models. AnnAGNPS, HSPF, LSPC, and SWAT are continuous models, used for analyzing long-term impacts of climate and hydrological changes and management practices on water quantity and quality in a watershed. AGNPS is a storm event model. Storm event models are used to predict water quantities and qualities, and analyze impacts of management practices, during and after individual storm events, especially extreme storm events that may cause flooding and move disproportionately large amounts of sediment and nutrients. Storm event model results are used in engineering designs of control or conservation structures and would be most useful for evaluating appropriate best management practices (BMPs) for TMDL implementation. As discussed below, some models, such as CASC2D/GSSHA and MIKE SHE, have the ability to perform both long-term continuous and storm event simulations.

The above models and a few other promising ones for TMDL are described and discussed here. Most of these models are included in the extensive review by Shoemaker et al. (2005), which includes general discussions on modeling, categorization of models based on their structures and capabilities, and outlines of research needs. In addition, Shoemaker et al. (2005) provide fact sheets for each of the models reviewed containing: contact information, download information, model overview (abstract), model features, model areas supported, model capabilities (conceptual basis, scientific detail, and model framework), scale (spatial and temporal), assumptions, model strengths, model limitations, application history, model evaluation, model inputs, user's guide, technical hardware and software requirements (computer hardware, operating system, programming language, and runtime estimates), linkage supported, related systems, sensitivity-uncertainty-calibration, model interface capabilities, and a complete list of source references.

\section{LOADING MODELS GWLF}

The Generalized Watershed Loading Functions (GWLF) model (Haith and Shoemaker, 1987; Haith et al., 1992) is used to predict monthly loadings of water, sediment, and nutrients, including $\mathrm{N}$ and phosphorous $(\mathrm{P})$, from nongauged watersheds with mixed land uses. The model considers the watershed as a single unit and aggregates loads from all land use areas into a watershed total. Surface runoff is based on the USDA Soil Conservation Service (SCS, 1972) runoff curve number method. Various storages and other water components are adjusted to satisfy daily water balance. Erosion from pervious areas is simulated using the Universal Soil Loss Equation (USLE) (Wischmeier and Smith, 1978) with calculations modified by a daily rainfall factor. An area-based sediment delivery factor is applied to erosion. The monthly sediment loads are computed from annual sediment load using relative monthly transport abilities computed as a power function of monthly runoff. Sediment can also be contributed from impervious areas through a daily buildup/ washoff routine. The model is based on the assumption that the relationship between erosion and sediment transport varies on a monthly basis, but that for each simulated year (April-March) there is no net deposition and no carryover of detached sediment from year to year.

For nutrient simulations, GWLF uses a loading function approach, where dissolved or particulate concentrations are associated with flow volumes or sediment loads, respectively, from various land uses or pollutant source inputs, such as groundwater, manure application, and septic system effluent. Best Management Practices (BMPs) can be simulated through land use changes, changes in loading factors, and application of efficiency factors during post-processing (Yagow, 2004).

Therefore, GWLF can be used for both sediment and nutrient ( $\mathrm{N}$ and $\mathrm{P}$ ) TMDLs for estimating loadings. Its strengths include: simplicity, the relatively small amount of input data required, the helpful user guidance for parameter evaluation, and the fact that it does not require calibration, although hydrologic calibration has been shown to be helpful where monitored data are available. The model's runtime estimates are seconds to minutes. GWLF's limitations include: the lack of ongoing user support, and the requirement for auxiliary post-processing procedures to simulate subwatersheds and account for many BMPs.

\section{PLOAD}

PLOAD (USEPA, 2001) is a simplified Geographic Information System (GIS) based model developed by CH2M HILL, a consulting firm, for calculating pollutant loads from watersheds. PLOAD estimates nonpoint loads of pollution on an annual average basis, for any user-specified pollutant, including total suspended solids (suspended sediment), total dissolved solids, biological oxygen demand, chemical oxygen demand, $\mathrm{P}, \mathrm{N}$, nitrate plus nitrite, total Kjeldahl N, ammonia, fecal coliform, lead, and zinc. The user may use either the export coefficient or the EPA's Simple Method approach to calculate nonpoint-source loads. The model requires GIS data and/or tabular inputs on land use, watershed, BMP site and area (optional), pollutant loading rates, impervious terrain factors, and point-source facility locations and loads (optional). PLOAD can be used for both sediment and nutrient TMDLs for estimating loadings.

\section{Receiving Water Models AQUATOX}

AQUATOX (USEPA, 2004; www.epa.gov/waterscience/ models/aquatox/about.html; accessed 9 Jan. 2006) can represent a variety of aquatic ecosystems, including vertically stratified lakes, reservoirs and ponds, and rivers and streams, and can simulate multiple environmental stressors (including nutrients, organic loadings and chemicals, and temperature) and their effects on a user-specified variety of algal, macrophyte, invertebrate, and fish communities. Therefore, AQUATOX can help to identify and quantify the cause and effect relationships between chemical water quality, the physical environment, and aquatic life in those aquatic ecosystems (Shoemaker et al., 2005).

The model uses differential equations to represent changing values of state variables and solves the equations using a numerical solution method. Time steps of 15 minutes to one day (smaller steps during rapid changes) are used in solving the equations. However, the reporting time step could vary from 0.1 day to 99 days (one day is normally used). Runtime 
estimates are reported to range from one second to several minutes. The model is suitable for nutrient TMDLs for analyzing receiving water qualities.

\section{BATHTUB}

BATHTUB (Walker, 1986) predicts lake and reservoir responses to nutrient loadings on a yearly basis based on in-lake/reservoir water quality state. It can compute average loads over one year or over the growing season. It can distinguish between the characteristics of a reservoir and those of a natural lake, including the effects of non-algal turbidity on transparency and algae responses to phosphorous. It summarizes information on in-lake water quality data and can also estimate nutrient loadings based on correlations of concentrations and flows (rating curves), although it is commonly used in combination with a loading model, such as GWLF (e.g., IEPA, 2004).

BATHTUB contains a number of regression equations based on a wide range of lake and reservoir data sets. It can treat the lake or reservoir as a continuously stirred, mixed reactor, or it can predict longitudinal gradients in trophic state variables in a reservoir or narrow lake. These trophic state variables include in-lake total $\mathrm{P}$ (TP), ortho-P, organic N, hypolimnetic DO, metalimnetic DO, chlorophyll concentrations, and Secchi depth (transparency). Uncertainty estimates are provided with predicted trophic state variables. The model can be used for nutrient TMDLs for analyzing receiving water quality.

\section{$C E-Q U A L-W 2$}

CE-QUAL-W2 (Cole and Wells, 2003) is a laterally averaged, two-dimensional (longitudinal and vertical) hydrodynamic and water quality model for rivers, lakes, reservoirs, and estuaries (best suitable for relatively long and narrow water bodies). The model is based on finite difference solutions of the governing partial differential equations using variable grid spacing (segment length and layer thickness) and internally adjustable time steps to ensure numerical stability. The hydrodynamic component of the model predicts water surface elevations, velocities, and temperatures, while the water quality component simulates 21 constituents, including nutrients, phytoplankton, and DO interactions during anoxic conditions. Runtime estimates are reported to be minutes to hours. The model can be used for nutrient TMDLs for analyzing receiving water quality.

\section{QUAL2E}

QUAL2E (USEPA, 1995; www.epa.gov/docs/QUAL2E WINDOWS/; accessed 9 Jan. 2006) is a one-dimensional, steady-state, and nonuniform flow and water quality model that simulates nutrient dynamics, algal production, and DO with the impact of benthic and carbonaceous demand in streams and rivers. It predicts temperature, DO, biochemical oxygen demand, ammonia, nitrate, organic $\mathrm{N}$, inorganic $\mathrm{P}$, organic $\mathrm{P}$, algae, and conservative and non-conservative substances. The streams or rivers are assumed to be trapezoidal and divided into homogeneous reaches, with each reach further subdivided into uniform segments or control volumes. Although the model is steady state, it can accommodate diurnal variations of temperature and dissolved oxygen. The governing equations are advection-dispersion-reaction equations with external sources and sinks. A flow balance is assumed, and steady nonuniform flow is used to solve the advection equation. The governing equations are numerically solved using an implicit finite difference scheme. The dispersion coefficient is an empirical function. The model accommodates uncertainty analyses, and runtime estimates are in minutes. More descriptions and discussion on QUAL2E are given in a companion article while discussing DO modeling (Vellidis et al., 2006).

QUAL2K (Chapra and Pelletier, 2003; www.epa.gov/ ATHENS/wwqtsc/html/qual2k.html; accessed 3 Feb. 2006), an enhanced version of QUAL2E, is also available. The enhancements include two forms of carbonaceous biological oxygen demand (slowly oxidizing and rapidly oxidizing), internal sediment processes, and simulations of $\mathrm{pH}$ and alkalinity. Runtime estimates are reported to be minutes to hours. Both QUAL2E and QUAL2K can be used for nutrient TMDLs for analyzing receiving water qualities.

\section{Other Receiving Water Models}

There are many other receiving water quality models that have potential for TMDL development and implementation, most of which are reviewed and categorized by Shoemaker et al. (2005) and Kalin and Hantush (2003). It is noteworthy to mention the Water Quality Analysis Simulation Program (WASP) (www.epa.gov/athens/wwqtsc/html/wasp.html; accessed 9 Jan. 2006). WASP is a detailed and versatile state-of-the-art receiving water quality model with dynamic one-, two-, or three-dimensional spatial simulation capabilities simulating both eutrophication, nutrient, and dissolved oxygen (EUTRO), as well as metals, toxics, and sediment (TOXI); it is also a computationally intensive model with runtime estimates of minutes to hours. More description and discussion on WASP can be found in the companion article discussing DO modeling (Vellidis et al., 2006). The model is suitable for both sediment and nutrient TMDLs for analyzing receiving water qualities.

\section{WATERSHED MODELS HSPF}

The Hydrological Simulation Program - Fortran (HSPF) (Bicknell et al., 2001) is a continuous model for simulating watershed hydrology and water quality for a wide range of conventional and toxic organic pollutants. It performs typically at an hourly time step and produces a time history of water quantity and quality at any point in a watershed. The watershed is divided into subwatersheds, each conceptualized as a group of pervious and impervious land uses all routed to a representative stream segment or a mixed reservoir. Routing is performed by assuming that the subwatersheds, streams, and the reservoirs (impoundments) are a series of one-dimensional reservoirs.

HSPF uses a comprehensive, physically based water budgeting procedure with interaction among the various storages and processes. It accounts for interception, infiltration, evapotranspiration, snowmelt, surface runoff, interflow, groundwater loss and recharge, and base flow; these are mostly represented by empirical equations. HSPF allows routing of in-stream flows and can simulate reservoir behavior as well.

Pervious land surface erosion and transport are modeled using exponential relationships for soil detachment, detached sediment washoff, and gully erosion. Sediment from impervious areas is also modeled with buildup/washoff routines. In-stream sediment transport, deposition, and scour of sediment are simulated for each of three particle-size 
classes (sand, silt, and clay) based on physical properties and using published equations.

HSPF includes very detailed subroutines of nutrient dynamics and calculates individual nutrient balances at a user-specified time step, representing a series of storages and phases with transport either by runoff in the dissolved phase or attached to sediment in the particulate phase. HSPF allows for detailed inputs of field operations and fertilization rates (management activities) through its special actions module. It simulates in-stream fate and transport of a wide variety of pollutants, such as nutrients, sediment, tracers, DO, biochemical oxygen demand, temperature, bacteria, and user-defined constituents, including pesticides.

BMPs can be simulated either through land use changes, a variety of special action functions that include direct reductions of input source loads and distributions, or through the Best Management Practice (BMPRAC) module. The BMPRAC module simulates simple removal fractions for a wide variety of constituents, including sediment and many forms of nutrients. These removal fractions can vary monthly or be constant.

Primary strengths of HSPF include: flexibility, ability to simulate a wide range of user-configurable inputs, modular structure that allows use of only those components needed for a specific application, and USEPA and USGS support. HSPF's limitations include large input data requirements, the need for monitored data in order to perform calibration, and a steep learning curve. Its runtime estimates are seconds, minutes, or even hours depending on the application. More descriptions and discussion on HSPF are given in the companion article discussing DO modeling (Vellidis et al., 2006). It is suitable for both sediment and nutrient TMDLs.

\section{LSPC}

The Loading Simulation Program in C++ (LSPC) (Tetra Tech, Inc., and USEPA, 2002) is a continuous watershed modeling system that uses HSPF algorithms for simulating hydrology, sediment, and general water quality on land, and includes a simplified component for simulating in-stream transport. The model can be configured for use in either simple or complex watersheds, depending on the application requirement and data availability. It has no inherent limitations in terms of the numbers of modeled subdivisions of land use and subwatersheds or of model operations, and is applicable to large, complex watersheds. The model produces output on the subwatershed or reach-segment level. Data management tools are included for evaluating output from multiple watersheds and multiple scenarios simultaneously. The Microsoft Visual $\mathrm{C}++$ programming architecture allows for integration of output with widely available database and spreadsheet programs.

LSPC simulates the hydraulics of complex natural and man-made drainage networks and variable groundwater surfaces. It is capable of simulating both peak flow and low flows at a variety of time steps, from sub-hourly to daily. For simulation within each subwatershed, processes are lumped by land use category and, therefore, the relative location of one land parcel to another is not represented. The model approaches a distributed model when smaller subwatersheds are used, although as in all models, the smaller the modeling sub-unit, the greater the resources needed to estimate parameter values and the longer the simulation times.
In-stream simulation is limited to well-mixed rivers and reservoirs with one-directional flow.

LSPC uses empirical relationships to represent physical processes and requires extensive calibration. Similar to HSPF, its runtime estimates range from seconds to hours, depending on spatial and temporal resolution and length of simulation period, and it is suitable for both sediment and nutrient TMDLs.

\section{SWAT}

The Soil and Water Assessment Tool (SWAT) (Neitsch et al., 2002) is a continuous simulation model that runs typically on a daily time step, simulates hydrology, weather, sedimentation, soil temperature, crop growth, nutrients, pesticides, and agricultural management. The watershed is divided into subwatersheds, each connected through a stream channel and further subdivided into hydrologic response units (HRUs) with unique combinations of soils and land uses. Simulations are performed at the HRU level and summarized in each subwatershed. The simulated variables (water, sediment, nutrients, and other pollutants) are routed through the stream network to the watershed outlet.

Hydrologic simulations are based on a daily water budget where change in soil water content is equal to precipitation minus surface runoff, evapotranspiration, percolation, and groundwater return (base) flow. Surface runoff is computed using the SCS (1972) runoff curve number method; the amount reaching the stream channel is computed using an exponential function with a lag coefficient. Evapotranspiration can be computed using three alternative well-publicized methods. Percolation and groundwater return flow are computed using exponential functions with empirical parameters. Lateral subsurface flow is computed simultaneously with percolation using a well-publicized kinematic storage model. All the surface, lateral subsurface, and base flow waters reaching the stream channels are routed through the channel network using a variable storage coefficient method (Williams, 1969) or the Muskingum routing method (Linsley et al., 1958). Transmission losses are determined while routing water through channels using the SCS (1983) method. In addition, canopy storage (interception) is computed for simulating crop growth. Infiltration rates are computed using the Green and Ampt (1911) infiltration equation for sub-daily (smaller time increment) simulations.

Erosion and sediment yield are estimated for each HRU with the Modified Universal Soil Loss Equation (MUSLE) (Williams, 1975), an enhancement of the USLE. Sediment is routed through the stream channel considering deposition and degradation processes and using a simplified equation (Williams, 1980) based on Bagnold's definition of stream power.

SWAT assumes that nitrate and organic $\mathrm{N}$ may be removed from the soil via mass flow of water. Amounts of nitrate-N contained in the runoff, lateral flow, and percolation are estimated as products of the volume of water and the average concentration of nitrate in a soil layer. Organic $\mathrm{N}$ transport with sediment is calculated with a loading function (McElroy et al., 1976; Williams and Hann, 1978) for individual runoff events. Plant use of $\mathrm{N}$ is estimated with a supply and demand approach where the daily plant $\mathrm{N}$ demands are calculated as the difference between the actual concentration of the element in the plant and the optimal concentration. The 
optimal concentration of the elements varies with growth stage (Jones, 1983).

SWAT assumes that $\mathrm{P}$ is not a mobile nutrient. The amount of soluble $\mathrm{P}$ removed in runoff is predicted using solution $\mathrm{P}$ concentration in the top $10 \mathrm{~mm}$ of soil, runoff volume, and a partitioning factor. Sediment transport of $\mathrm{P}$ is simulated with a loading function, as described for organic $\mathrm{N}$ transport. Plant uptake of $\mathrm{P}$ is calculated in the same way as N. Nutrient transformations in the stream are controlled by the in-stream water quality component of the model. The in-stream kinetics used in SWAT for nutrient routing are adapted from QUAL2E (Brown and Barnwell, 1987). The model tracks nutrients dissolved in the stream and nutrients adsorbed to the sediment. Dissolved nutrients are transported with the water, while those sorbed to sediments are allowed to be deposited with the sediment on the channel bed.

SWAT is a parameter-intensive model using physically based and empirical relations that has physically based parameters. Its input data are readily available from government agencies. It is a relatively robust (computationally efficient) model with runtime estimates of minutes to less than an hour. It is a long-term yield model and is not for detailed single-event flood routing. More discussion of SWAT can be found in the companion article discussing DO modeling (Vellidis et al., 2006). It is suitable for both sediment and nutrient TMDLs.

\section{AGNPS}

The Agricultural NonPoint Source (AGNPS) model (Young et al., 1987) is a single-storm event model. It simulates surface runoff, soil erosion, and transport of sediment, N, P, chemical oxygen demand (COD), and pesticides from nonpoint and point sources resulting from a single rainfall event. The model generates total or average responses for a storm event considering the storm duration as one time step. The watershed is divided into uniform square areas (cells).

AGNPS computes runoff volume using the SCS (1972) runoff curve number method. Peak runoff rate for each cell is computed using an empirical function of drainage area, channel slope, runoff volume, and watershed length-width ratio. Computation of soil erosion due to rainfall is based on the USLE. Detached sediment is routed using sediment transport and depositional relations based on a steady-state sediment continuity equation, effective sediment transport capacity, particle fall velocity, and Manning's equation. A modification to Bagnold's stream power equation is used for the effective sediment transport capacity.

AGNPS simulates chemical transport in soluble and sediment-adsorbed phases. Nutrient yield in the sedimentadsorbed phase is empirically calculated using sediment yield, nutrient ( $\mathrm{N}$ or $\mathrm{P}$ ) content of the soil, and an enrichment ratio. Soluble $\mathrm{N}$ or $\mathrm{P}$ contained in runoff is computed simply by multiplying an extraction coefficient of $\mathrm{N}$ and $\mathrm{P}$, the mean concentration of soluble $\mathrm{N}$ or $\mathrm{P}$ at the soil surface during runoff, and total runoff. AGNPS uses an $\mathrm{N}$ decay factor when simulating $\mathrm{N}$ movement through stream channels. COD is calculated based on runoff volume, with average concentration in that volume as the background concentration obtained from the literature. The COD is assumed to be additive without any loss.

AGNPS accounts for nutrient and COD contributions from point sources, such as feedlots, springs, and wastewater treatment plants, and estimated sediment contributions from stream bank, stream bed, and gully erosion as user input values. AGNPS simulates impoundments and their impacts on reducing peak discharges, sediment yield, and yield of sediment-attached chemicals.

AGNPS is spatially distributed but temporally lumped, and is relatively robust with runtime estimates in minutes; it is suitable for both sediment and nutrient TMDLs.

\section{AnnAGNPS}

The Annualized Agricultural NonPoint Source (AnnAGNPS) model (Bingner and Theurer, 2001) is a continuous model, developed by extensively revising and upgrading the AGNPS storm event model. AnnAGNPS simulates the same processes as AGNPS (surface runoff, soil erosion, and transport of sediment, nutrients, and pesticides) plus snowmelt, irrigation, subsurface flow, tile drain flow, feedlots, and gullies at continuous daily or sub-daily time steps. Unlike AGNPS, AnnAGNPS divides the watershed into homogeneous drainage areas, which are then integrated together by simulated rivers and streams, routing the runoff and pollutants from each area downstream.

AnnAGNPS hydrologic simulations are based on a simple water balance approach, considering precipitation, snowmelt, irrigation, surface runoff, percolation, evapotranspiration, subsurface lateral flow, and tile drainage flow. The runoff volume routine is unchanged, i.e., the SCS (1972) runoff curve number method, and the sediment yield routine was upgraded to the Revised Universal Soil Loss Equation (RUSLE) (Renard et al., 1997) for erosion computations. The Hydro-geomorphic Universal Soil Loss Equation (HUSLE) was introduced for computations of sediment delivery ratios. Output is expressed on an event basis for selected stream reaches and as source accounting (contribution to outlet) from land or reach components over the simulation period.

Similar to AGNPS, AnnAGNPS is also both physically and empirically based, and is relatively robust with runtime estimate in minutes; it is suitable for both sediment and nutrient TMDLs.

\section{CASC2D/GSSHA}

The Gridded Surface Subsurface Hydrologic Analysis (GSSHA) model (Downer and Ogden, 2002) is a continuous as well as storm event model. It is a reformulation and enhancement of the CASCade of planes in 2-Dimensions (CASC2D) model (Ogden and Julien, 2002), a physically based storm event and continuous hydrologic and sediment transport model. GSSHA is also a physically based, storm event, continuous, non-steady state, and distributed parameter watershed response model that simulates continuous soil moisture, precipitation distribution, snow accumulation and melting, rainfall interception, infiltration, evapotranspiration, surface water retention, two-dimensional overland flow, one-dimensional channel flow, two-dimensional unsaturated zone lateral flow, saturated zone groundwater flow, and erosion, transport, and deposition of sediment in overland and channel segments. It has additional features to simulate lakes, wetlands, detention basins, hydraulic structures, and full-dynamic wave routing with tidal influence. The watershed is divided into two-dimensional square overland grids (typical size 30 to $200 \mathrm{~m}$ ) and one-dimensional channels.

GSSHA is a computationally intensive model with computational time steps typically in seconds to minutes 
depending on the numerical stability of the finite difference solution scheme solving the governing equations. Runtime estimates are minutes to hours, and GSSHA can be used for sediment TMDLs only.

\section{MIKE SHE}

MIKE SHE (www.dhisoftware.com/mikeshe/Interface/ index.htm; accessed 6 Jan. 2006; Refsgaard and Storm, 1995) is a continuous as well as storm event model. Based on the Système Hydrologique Européen (SHE) model, MIKE SHE is a physically based, distributed, and comprehensive watershed model simulating a broad range of hydrologic, hydraulic, and transport process, including water, sediment, and water quality parameters in two-dimensional overland grids (rectangular or square), one-dimensional channels, and one-dimensional unsaturated and three-dimensional saturated flow layers. A watershed is divided into such multi-dimensional flow segments.

MIKE SHE uses user-defined variable time steps, typically seconds to minutes depending on the numerical stability of the finite difference solution scheme solving the governing equations. Similar to GSSHA, runtime estimates of MIKE SHE are minutes to hours, but MIKE SHE can be used for both sediment and nutrient TMDLs.

\section{DWSM}

The Dynamic Watershed Simulation Model (DWSM) (Borah et al., 2002b) is a storm event, distributed, and physically based model for simulations of surface and subsurface storm water runoff, propagation of flood waves, soil erosion, and entrainment and transport of sediment and agricultural chemicals in primarily agricultural watersheds during single or a series of rainfall events. The watershed is divided into subwatersheds, specifically, into one-dimensional overland planes, channel segments, and reservoir units. User-specified time steps, typically in minutes, are used for the computations.

Rainfall excess is computed using two alternative procedures: an extension of the SCS (1972) runoff curve number method, or a detailed procedure involving computations of interception and infiltration losses. The excess rainfall over the overland planes and through the channel segments is routed using the analytical solution of the kinematic wave equations with approximate shock-fitting. Combined subsurface, tile drain, and base flows through soil layers under the overland planes are simulated using a kinematic storage model and an effective lateral saturated hydraulic conductivity $(E L S H C)$ parameter. Flows through reservoirs are routed using the storage-indication or modified Puls method. The model has only three calibration parameters with the curve number procedure: curve number, $E L S H C$, and Manning's roughness coefficient. The model accommodates distributed (spatial variation) rainfall inputs and parameter values for the overland planes and/or channel segments.

Soil erosion and sediment transport are simulated and routed along with water through the overland planes and stream segments. All the inflowing sediment into a lake, reservoir, or impoundment is assumed to be trapped and, therefore, not routed through these units. Sediment is divided into a number of particle size groups or five specific size groups: sand, silt, clay, small aggregate, and large aggregate. Soil erosion due to raindrop impact is calculated using a proven relationship in terms of rainfall intensity squared (Borah et al., 2006), which is similar to the USLE, and a reduction factor representing the ponding water depth. The eroded (detached) soil is added to an existing detached (loose) soil depth from where entrainment to runoff takes place. Erosion due to flow shear stress and deposition depends on sediment transport capacity of the flow and the sediment load (amount of sediment already carried by the flow). Sediment transport capacity is computed using published proven formulas. These processes are interrelated, and the sediment continuity (mass conservation) equation is analytically solved to keep track of erosion, deposition, bed elevation, and sediment discharges along the overland planes and channel segments.

The agricultural chemical transport component of DWSM involves simulations of mixing of nutrients and pesticides and transport of these chemicals with surface runoff in dissolved form, and with sediment in adsorbed form, in each of the overland planes and channel segments, similar to the hydrologic and sediment components. The model assumes equilibrium between dissolved and adsorbed phases of the chemicals, governed by a linear adsorption isotherm. The soil profile is divided into small homogeneous depth increments where water contents and chemical concentrations are computed by routing infiltrating rainwater and solutes through them. When runoff begins, exchange of chemicals from a mixing soil layer, containing the chemicals in dissolved form, with surface runoff is simulated using the concept of non-uniform mixing of runoff with the mixing layer. Exchange of chemicals in adsorbed forms with the eroded and deposited sediments is computed based on preference factors of the individual size groups. The entrained chemicals are routed along slope lengths in dissolved form with surface runoff and in adsorbed form with the transported sediment using analytical solutions of continuity (mass conservation) equations.

DWSM is a robust model because of the analytical solutions of the governing equations, and it has the advantage of requiring few calibration parameters. Its runtime estimates are a few seconds, much less than a minute. Its preferable use is for sediment TMDLs (DWSM-HydroSed version) in watersheds up to $250 \mathrm{~km}^{2}$, although it may be useful for nutrient TMDLs (DWSM-Agchem version) in watersheds from field size to $100 \mathrm{~km}^{2}$ (Borah and Bera, 2004).

\section{KINEROS2}

KINEROS2 (www.tucson.ars.ag.gov/kineros/; accessed 6 Jan. 2006) is a single-storm event model. It is an upgrade of the KINEROS (Woolhiser et al., 1990), a distributed physically based model simulating interception, infiltration, surface runoff, soil erosion, and sediment transport in small agricultural and urban watersheds during a single rainfall event. The model represents a watershed by an abstraction into a tree-like network sequence of planes and channels and numerically solves the partial differential equations describing one-dimensional overland and channel flows, erosion, and sediment transport by using finite-difference techniques. Computational time steps are normally in minutes but could be in seconds depending on the numerical stability of the solutions. The model accommodates pipe flows, pond elements, infiltrating surfaces, and partially paved surfaces for urban areas.

Because of the numerical solutions, KINEROS2 is also a computationally intensive model. For better performance, the developers (Smith et al., 1995) recommended its 
application to watersheds up to $10 \mathrm{~km}^{2}$. Runtime estimates are reported to be seconds to minutes, and it can be used for sediment TMDLs only.

\section{Other Watershed Models}

There are other continuous, storm event, and combined continuous-storm event watershed models having TMDL application potentials. Those may be found in the citations made earlier. Borah and Bera (2003), in addition to critically reviewing AGNPS, AnnAGNPS, CASC2D, DWSM, HSPF, KINEROS, MIKE SHE, and SWAT, reviewed ANSWERS storm event (Beasley et al., 1980), ANSWERS continuous (Bouraoui et al., 2002), and PRMS storm event (Leavesley and Stannard, 1995) models. ANSWERS storm event and PRMS storm event may be used for sediment TMDLs, but ANSWERS continuous may be used for both sediment and nutrient TMDLs.

A few other noteworthy models having TMDL potentials are mentioned here. The Water Erosion Prediction Project (WEPP) model (Flanagan and Nearing, 1995; http://topsoil.nserl.purdue.edu/nserlweb/weppmain/wepp.html; accessed 7 Jan. 2006) is used for continuous simulations of hydrology and state-of-the-art hillslope erosion processes applicable to hillslopes and small (field size) agricultural watersheds, and it is therefore suitable for sediment TMDLs for such watersheds. The Storm Water Management Model (SWMM) (Huber and Dickinson, 1988; www.epa.gov/ ednnrmrl/models/swmm/index.htm; accessed 7 Jan. 2006) performs storm event and continuous simulations of hydrology, pollution, and limited erosion in urban watersheds and is therefore suitable for nutrient TMDLs for such watersheds. The Riparian Ecosystem Management Model (REMM) was developed by the USDA-ARS Southeast Watershed Research Laboratory, Coastal Plain Experiment Station, Tifton, Georgia (http://sacs.cpes.peachnet.edu/remmwww/remm/ remmoldwww/default.htm; accessed 7 Jan. 2006) to quantify water quality benefits of riparian buffers through simulations of surface and subsurface water, sediment, nutrients, sequestration, cycling, and vegetative growth in riparian forest systems on a daily time step. The Vegetative Filter Strips hydrology and sediment transport Model (VFSMOD) (Muñoz-Carpena et al., 1999) evaluates flow/velocity reduction and sediment trapping efficiency of vegetative filter strips by simulating detailed hydrology and sediment transport processes on field-scale vegetative filter strips.

The REMM and VFSMOD models may be used in evaluating riparian buffers and vegetative filter strips as BMPs while developing and implementing TMDLs; thus, these two models are categorized separately here as BMP models. REMM is useful for both sediment and nutrient TMDLs, and VFSMOD is useful for sediment only. The Agricultural Policy/Environmental eXtender (APEX) model (Williams and Izaurralde, 2006) was developed based on the Environmental Policy Integrated Climate (EPIC) model, previously known as the Erosion Productivity Impact Calculator model (Williams, 1995). APEX is another noteworthy BMP evaluation model suitable for both sediment and nutrient TMDLs. APEX includes extensive BMPs (land management strategies) for whole farm (small watershed) management, considering sustainability, erosion (wind, sheet, and channel), economics, water supply and quality, soil quality, plant competition, weather, and pests. Management capabilities include irrigation, drainage, fur- row diking, buffer strips, terraces, waterways, fertilizer manure management, lagoons, reservoirs, crop rotation and selection, pesticide application, grazing, and tillage. Background information on economic modeling and description of such existing models may be found in the companion article on economic modeling (Bosch et al., 2006).

\section{Model Applications}

All of the models described here have been field tested and verified. Numerous applications of these models can be found in peer-reviewed literature and government publications. Some of those applications are for TMDLs. Although the other applications are not for TMDLs, their application studies are useful to TMDL modelers in choosing the most suitable models for their TMDLs.

As part of their reviews, Shoemaker et al. (2005) noted evaluations and application histories of all the models they reviewed. A few of the models, such as the HSPF and SWAT, have been extensively applied nationally and internationally, including in TMDL developments, especially after their inclusion into BASINS.

Borah and Bera (2004) critically reviewed twelve, seventeen, and eighteen applications of, respectively, HSPF, SWAT, and DWSM and concluded that HSPF, SWAT, and DWSM are promising models: HSPF for long-term continuous simulations in mixed agricultural and urban watersheds, SWAT for long-term continuous simulations in predominantly agricultural watersheds, and DWSM for storm event simulations in agricultural and suburban watersheds. HSPF and SWAT were found suitable for predicting yearly flow volumes and sediment and nutrient loads. Monthly predictions were generally good, except for months having extreme storm events and hydrologic conditions. Daily simulations of extreme flow events were poor. DWSM reasonably predicted distributed flow hydrographs, as well as concentration or discharge graphs of sediment and nutrients at small time steps resulting from rainfall events. Combined use of these and other complementary models was encouraged.

Saleh and Du (2004) evaluated the HSPF and SWAT models side by side on the Upper North Bosque River watershed $\left(921 \mathrm{~km}^{2}\right)$ in Texas and found that "SWAT generally proved to be a better predictor of nutrient loading during both calibration and verification periods." Both models were calibrated for daily flow, sediment, and nutrients at five stream sites for an 18-month period and verified for daily and monthly time steps for a four-year period.

Kalin and Hantush (2003) evaluated the performances of the KINEROS2 and GSSHA models in simulating flow, erosion, and sediment transport on a USDA experimental watershed (34 ha) near Treynor, Iowa. They found that GSSHA performed better than KINEROS2 in simulating flow. However, KINEROS2 was more robust (efficient) and simulated erosion and sediment transport better than GSSHA. These results are expected, because GSSHA uses 2-D diffusive wave equations, which are more physically based and complicated flow equations than the 1-D kinematic wave equations used by KINEROS2. At present, both the models simulate sediment only and lack nutrient components. Their capabilities to simulate BMPs are also limited. 
Borah et al. (2002a) applied the AGNPS storm event model to the 2,400 $\mathrm{km}^{2}$ Lake Decatur-Upper Sangamon River watershed in Illinois and qualitatively evaluated the effectiveness of various combinations of spatially distributed $\mathrm{N}$ application rates and conservation practices (BMPs) in reducing nitrate- $\mathrm{N}$ discharge into Lake Decatur, a water supply reservoir. In another study, Borah et al. (2004) applied the DWSM's storm event hydrology to the above-mentioned watershed for studying the effects of subsurface (including tile drainage) flows on stream flows. They also applied DWSM's hydrology and sediment components to one of its tributary subwatersheds (Big Ditch: $100 \mathrm{~km}^{2}$ ) for various hydrologic and sediment transport investigations, including scaling effects. In the same study, DWSM's hydrology and sediment components were also applied to the $250 \mathrm{~km}^{2}$ Court Creek watershed in Illinois to prioritize critical areas for the Illinois Conservation Reserve Enhancement Program and to evaluate the impacts of impoundments (BMPs) on downstream flows and sediment discharges.

More applications of nutrient models are given in the companion article on DO models while discussing applications of DO models (Vellidis et al., 2006). Modeling studies involving development and implementation of TMDLs are described below.

\section{TMDL Modeling STudies}

There are thousands of TMDLs already developed, being developed, or that will be developed throughout the U.S., and models are used in most of them, including some of the models discussed here. Details of such studies can be found in the literature or state web sites. A few of the TMDL modeling studies as available to the authors through their involvements are discussed here as examples.

Simple models are commonly being used for TMDL studies. For example, in Illinois, the loading model GWLF and the receiving water model BATHTUB, both relatively simple models, are mostly used (IEPA, 2006). The primary reason is lack of sufficient data for sophisticated model development. Sophisticated models such as SWAT have been used in Illinois only for qualitative evaluations. While developing a TMDL for impairment by $\mathrm{P}$ in the 23 ha Altamont New Reservoir in Illinois (IEPA, 2004), GWLF was used to estimate monthly flows and P loadings from the $3 \mathrm{~km}^{2}$ drainage area into the reservoir, and BATHTUB was used to predict average annual TP concentrations in the reservoir. The models were run from April to March of the following year to coincide with the soil erosion cycle because GWLF assumes no deposition; all the sediment generated within a given year flows out of the watershed during the same year. The models were useful in determining the effects of nutrient management and conservation tillage practices. However, load reduction effects of filter strips and wetlands could only be estimated based on literature values due to limitations of the GWLF model.

In another Illinois TMDL study (IEPA, 2003), the BATHTUB model was used to predict annual average TP concentration in the 137 ha Charleston Side Channel Reservoir in response to yearly $\mathrm{P}$ load as estimated from observed flow and concentration data. The reservoir is replenished by its 523 ha drainage basin and water pumped from the Upper Embarras River, which has a drainage area of $2,040 \mathrm{~km}^{2}$. The SWAT model was used to predict distributed annual average TP loads from the Upper Embarras River watershed for determining qualitatively relative magnitudes of P loads from nonpoint sources.

GWLF has also been used in Virginia for sediment and $P$ TMDLs, where a reference watershed approach is used for setting TMDL target loads. The intent of this approach is to provide guidance for staged implementation. Pennsylvania has supported development of the ArcView interface and database (AvGWLF) for statewide application of GWLF within the state for use with TMDL development (Evans et al., 2001).

Rosenthal et al. (2001) conducted an analysis in the Arroyo Colorado River watershed in Texas as part of a TMDL study to determine the impacts of implementing BMPs in different areas of the watershed. The watershed has a mixture of urban and agricultural lands. Low DO has been measured in the lower part of the watershed. The suspected cause of these low readings is excessive nutrient and sediment loadings into the river. Sediment and nutrient loadings were simulated by SWAT for the outlet of the watershed. The SWAT model estimated an in-stream reduction of $50 \%$ for nitrate and $\mathrm{P}$ with a $50 \%$ reduction in fertilizer application rate (120 to $\left.60 \mathrm{~kg} \mathrm{ha}^{-1}\right)$.

In the Leon River watershed $\left(9,000 \mathrm{~km}^{2}\right)$ in Texas, nonpoint sources of pollution from dairy manure fields are a concern. SWAT was applied to this watershed, and model simulations showed as high as $3.9 \mathrm{~kg} \mathrm{ha}^{-1}$ nitrate levels and $0.03 \mathrm{~kg} \mathrm{ha}^{-1}$ of soluble $\mathrm{P}$ at the outlet (Rosenthal and Hoffman, 1999). Average simulated annual sediment loadings were $0.33 \mathrm{t} \mathrm{ha}^{-1}$. Subwatersheds in the lower part of the watershed had higher loadings. As a result, filter strips have been installed within each subwatershed as a means of reducing loadings into the streams and rivers. Modeling results were used to select monitoring stations in the watershed, which is required for TMDLs, and this will help: (1) to determine the cause of impairment (e.g., sediment and/or nutrients) and (2) to determine effectiveness of TMDLs. Installation of monitoring stations were recommended for subbasins with high simulated nutrient and sediment loadings.

A TMDL-related study of the upper North Bosque River watershed $\left(933 \mathrm{~km}^{2}\right)$ in Texas was performed by combining the SWAT and APEX models (Saleh et al., 2000). This watershed has the largest production of milk within Texas. Runoff from the manure application fields in this watershed was delivering excessive nutrients into the Bosque River system. The two models were used to capitalize on the strengths of each: the APEX model was run to simulate the effect of buffer strips on the edge of field loadings of nutrients and sediment, and the output loadings were then input into the SWAT model to simulate transport and fate through the watershed. A TMDL case study of the entire North Bosque River watershed $\left(4,277 \mathrm{~km}^{2}\right)$ and Lake Waco, using the SWAT watershed and CE-QUAL-W2 receiving water quality models, is described below.

\section{North Bosque River Watershed ANd LAKe Waco Modeling: A TMDL CASE Study In TeXas}

The $4,277 \mathrm{~km}^{2}$ North Bosque River watershed in north central Texas discharges into Lake Waco (surface area 2,940 ha and volume 17,800 ha-m at conservation pool). Lake Waco is a drinking-water supply reservoir for a population of about 150,000 that includes the city of Waco and surrounding communities. The North Bosque River was 
listed on the 1998 303(d) list for nutrient impairments and excessive aquatic vegetation under Texas narrative criteria. Environmental studies were used to assess the degree of nutrient enrichment in the watershed, evaluate nutrient impacts on biological production, derive nutrient targets, determine nutrient sources, and evaluate strategies for nutrient control through application of environmental models.

\section{Impairments}

Monitoring data corroborated the nutrient enrichment and excessive suspended algal concentrations that had resulted in the section 303(d) listing of two segments of the North Bosque River. $\mathrm{P}$ was determined to be the limiting nutrient in both the North Bosque River and Lake Waco. Soluble reactive $\mathrm{P}\left(\mathrm{PO}_{4}-\mathrm{P}\right)$ was linked to aquatic plant growth through bioassay studies in water bodies of the watershed. The following target ranges were established to control algal growth based on average annual concentrations of $\mathrm{PO}_{4}-\mathrm{P}: 15$ to 50 parts per billion (ppb) $\mathrm{PO}_{4}-\mathrm{P}$ in the North Bosque River, a tentative target of $30 \mathrm{ppb}$ in the lower portion of the North Bosque River, and a summer mean concentration of 8 to $14 \mathrm{ppb}$ for the lacustrine portion of Lake Waco, with a preferred target of $10 \mathrm{ppb}$. An analysis of stream flow and $\mathrm{P}$ data identified dairy manure application fields and municipal wastewater treatment plants as the primary controllable contributors of $\mathrm{PO}_{4}-\mathrm{P}$ for addressing in the TMDLs. Various control strategies were evaluated for these two controllable sources using the predictive capabilities of SWAT on the Bosque River watershed and CE-QUAL-W2 on Lake Waco.

\section{Modeling Using SWAT and CE-QUAL-W2}

SWAT was used to simulate nutrient loading contributions from municipal WWTPs and the various land uses in the Lake Waco-Bosque River watershed, and the subsequent transport of the nutrient loadings to receiving streams, such as the North Bosque River and its tributaries. CE-QUAL-W2 (Cole and Buchak, 1995) was used to simulate conditions in Lake Waco. The modeling methodology required the linkage of the results (or output) from SWAT as input to CE-QUALW2. Specifically, SWAT output was used to define quantity and quality of inflows from tributaries to Lake Waco.

\section{Calibration}

Calibration of SWAT was approached as a two-step process: calibration to long-term (35+ years) annual stream flow records from the U.S. Geological Survey gauging stations on the North Bosque River at Hico (an upstream station) and at Valley Mills (a downstream station), and calibration to short-term (3+ years) stream flow and water quality data from selected Texas Institute for Applied Environmental Research (TIAER) monitoring stations. Santhi et al. (2001a) concluded that in most instances SWAT model predictions were satisfactorily close to observed values for use of the model to assess nutrient concentrations and loadings in the Lake Waco-Bosque River watershed.

Calibration of the modeling system for Lake Waco was also approached in a two-step process. In the first step, CE-QUAL-W2 was calibrated using data from monitored major tributaries of Lake Waco (i.e., North Bosque River, Hog Creek, Middle Bosque River, and South Bosque River) as inputs. In the second step, CE-QUAL-W2 used SWAT results to define tributary inflows and loadings to Lake Waco. This two-step calibration process was undertaken because the extensive monitoring data would more accurately represent actual tributary inflows and loadings to the reservoir than SWAT predictions. By first calibrating CEQUAL-W2 using tributary inflows and loadings defined by the more accurate of the two sources, the possibility of adjusting the model erroneously during the calibration process as a result of inaccuracies in simulated tributary input was minimized. The combined modeling system of SWAT and CE-QUAL-W2 reproduced the general trends of soluble reactive phosphorus and, therefore, was deemed to be sufficiently accurate to evaluate the response of Lake Waco to alternative $\mathrm{P}$ control strategies. Details on calibration and application of these models to the Lake Waco-North Bosque watershed can be found as follows: SWAT in Santhi et al. (2001a, 2001b), CE-QUAL-W2 in Flowers et al. (2001), and both models in Flowers et al. (2000).

\section{BMP Evaluations}

Once the watershed model SWAT and reservoir model CE-QUAL-W2 were calibrated, they were applied to evaluate the response of receiving waters to various $\mathrm{P}$ control strategies (or scenarios), which included future growth conditions over a 20-year planning horizon and the following practices: effluent limitations for $\mathrm{P}$ imposed on municipal wastewater treatment plants (WWTPs), removal (export) of dairy cow manure from the watershed, reductions of $\mathrm{P}$ in dairy cow diets, and reduced manure application rates based on the $\mathrm{P}$ agronomic rate. Present and future conditions for these scenarios were described in Easterling (2000). Model simulations showed that the level of control strategies considered under projected future growth conditions was not enough to achieve target concentrations in both the North Bosque River and Lake Waco.

\section{Cheney Lake Watershed Modeling: A TMDL Case STUdY In Kansas}

The 2,400 $\mathrm{km}^{2}$ Cheney Lake watershed, drained by the North Fork Ninnescah River and associated tributaries, in south central Kansas produces $60 \%$ of the water supply for about 350,000 people in the Wichita area and is an important recreational resource for the area. The contributing land use is predominately agricultural and consists mainly of pasture and croplands with corn, grain sorghum, soybeans, and wheat cultivations. Improving the water quality of Cheney Lake is an important objective of federal, state, and local water managers. The Cheney Lake Task Force was formed in 1992, applied for Section 319 funding from the USEPA through the Kansas Department of Health and Environment (KDHE) in 1994, and received funds to implement the management plan in 1995.

\section{Watershed Monitoring and Impairments}

Nutrient enrichment has caused frequent summer algal blooms in Cheney Lake, which create taste and odor problems in drinking water withdrawn from the lake. Historical water quality data indicate that sedimentation has caused additional water quality problems in the lake (Pope, 2002). Thus a water quality monitoring study of the Cheney Lake watershed began in 1996 to evaluate potential degradation by nutrients and suspended sediment (Pope and Christensen, 1997).

Water quality constituents of particular concern in the Cheney Lake watershed are P, nitrate, and total suspended 
solids. Mean concentrations of each of the constituents examined exceeded the Cheney Lake Task Force stream-water quality goal for at least one of the stream flow conditions evaluated (Milligan and Pope, 2001). Most notably, mean base flow and mean long-term concentrations of TP and mean base flow concentrations of dissolved nitrate exceeded the goals of $0.05,0.10$, and $0.25 \mathrm{mg} \mathrm{L}^{-1}$, respectively, at all five sampling sites upstream from the lake. Additionally, the long-term stream-water quality goal for dissolved nitrate was exceeded by the mean concentration at one upstream sampling site, and the base flow total suspended solids goal (20 $\mathrm{mg} \mathrm{L} \mathrm{L}^{-1}$ ) and long-term total suspended solids goal (100 $\left.\mathrm{mg} \mathrm{L}^{-1}\right)$ were each exceeded by mean concentrations at three upstream sampling sites.

Cheney Lake TMDL sampling by KDHE showed elevated TP concentrations (averaging $117 \mathrm{ppb}$ ). Seventy-one percent of the samples during the KDHE sampling period were over $100 \mathrm{ppb}$. Light was indicated as the primary limiting factor for algal growth. Surface water in Cheney Lake has high turbidity, dominated by inorganic materials. The lake is very open to the wind, and sediment re-suspension is evident. Results of the USGS study (Milligan and Pope, 2001) indicate high concentrations of TP. The average TP concentration was $190 \mathrm{ppb}$, and only one of the USGS samples had a TP concentration below $100 \mathrm{ppb}$. Much of the TP coming into Cheney Lake is sediment attached, mainly on finer particles. The $\mathrm{P}$ concentrations in sediment averaged $450 \mathrm{mg} \mathrm{kg}^{-1}$ and increased during the study. This evidence was used to implement a TMDL to address the eutrophic conditions in the lake. The implementation plan assumed that if sufficient agricultural BMPs were installed, the full use of Cheney Lake could be regained.

\section{Watershed Modeling using AGNPS}

The Cheney Lake Task Force used a January 1995 to October 2000 modeling study to locate BMPs in the watershed. The study included an integrated modeling process, which combined remote sensing, GIS, and the AGNPS model, to assess water quality conditions in the watershed. Landsat Thematic Mapper (TM) images were used to obtain land cover information in the watershed, including subclasses of rangeland and wheat based on the estimates of vegetative cover and crop residue (Bhuyan et al., 2002a, 2002b), respectively. USLE cropping factors (C-factors) were assigned to land cover classes. Continuous antecedent moisture content ratios were developed (Bhuyan et al., 2003a, 2003b) for the subwatersheds during the storm events and were used to adjust the SCS curve numbers. A relationship was developed between storm amounts and estimated energy intensity (EI) values using a probability method (Koelliker and Humbert, 1989) for running the AGNPS model.

An AGNPS-ARC INFO interface was used to extract input parameters from several GIS layers for the AGNPS model during selected storm events for subwatersheds. Measured surface water quantity and quality data for these storm events were obtained from USGS stream gauging stations for calibration and validation of the model. Base flow separation was done to remove the base flow fraction of water, total suspended sediments, total N (TN), and TP from the total stream flow. Several model parameters were calibrated using measured water quality data, and the model was run on different subwatersheds to evaluate modeling efficiency.

The modeling process was found to be effective for smaller subwatersheds having adequate rainfall data (Marzen et al., 2000), but the process was less satisfactory for large subwatersheds with substantial variation in rainfall and land cover. This is because AGNPS uses uniform rainfall throughout the modeled watershed or subwatershed. However, the integrated modeling process was useful for the Task Force to assess the water quality of subwatersheds and to identify subwatersheds or areas within the watershed where practices are expected to have the largest impact on water quality.

\section{Advancing Modeling Technology}

Modeling of hydrology and transport of sediment and nutrients has advanced tremendously since the middle part of the 20th century. Numerous models have been developed with various capabilities, many of which are useful for TMDLs, as discussed above. It is clear from the above discussion that each model has strengths and weaknesses. Research on advancing modeling technology will continue. Advances may be made by making the best use of existing models, enhancing the existing models, and developing new models or supplemental components.

Making the best use of existing models, however, can be a challenging task. One must fully understand the background, potentials, and limitations of a model before using it. Extrapolation or stretching of a model beyond its limit must be avoided. Full documentation is the key to the best use of a model and avoiding any misuses. Without good documentation, a user may have to spend tremendous amounts of time and resources to find out key facts about a model.

Further development should be focused on existing scientifically sound (physically based) and proven robust models or techniques. Other scientifically sound (physically based) models and techniques should also be advanced by making them robust, increasing their ease of use with graphical user interfaces, and providing application examples. Models must be presented and documented in a fully transparent manner.

Extensive education and training with model applications and demonstrations are needed for understanding the potentials and limitations of a model and making the best use of it. In this section, some of the current activities and future research needs for advancing hydrology, sediment, and nutrient modeling technologies needed for TMDL studies are discussed.

\section{Model EnHANCEMENTS GWLF Enhancements}

A channel erosion component has been added in the Penn State version of GWLF (AvGWLF; Evans et al., 2001, 2003) as well as a Virginia Tech modification (Yagow, 2004). A post-processing Pollution Reduction Impact Comparison Tool (PRedICT) is also under development at Penn State to enable inclusion of a wider menu of BMPs (Penn State, 2006). Inclusion of GWLF in the BASINS interface would help to standardize its use with TMDLs and provide a basis for user support. 


\section{SWAT Enhancements}

Due to the widespread use of SWAT in TMDL studies, numerous studies are currently being conducted to improve and enhance its performance. Some of these enhancements are occurring through a project that is providing a midcourse reevaluation of the initial North Bosque River TMDLs. Houser et al. (2004) reported on the process of enhancing SWAT to allow manure application rates to change dynamically within a simulation as a function of soil test $\mathrm{P}$.

In another study, Saleh (2004) has developed the SWAPP (SWAT/APEX Programs) program to facilitate the simultaneous use of the SWAT and APEX (Williams et al., 2000) models. The advantages of SWAPP are that: (1) field units within APEX have spatial relationship and can be routed within a subbasin in a specified order, (2) APEX enables simulation of simultaneous multiple cropping, (3) APEX allows simulation of filter strips as a physically based process, and (4) APEX simulates detailed management practices related to farm animal productions, economic impacts of BMPs, and wind erosion, all of which are not currently possible with the SWAT model.

Borah et al. (2005) is enhancing SWAT's storm event hydrologic simulations by incorporating a combination of an extension of the SCS runoff curve number procedure for rainfall excess computations and a robust (efficient) analytical solution of the kinematic wave equations from the storm event DWSM model. Du et al. (2005) have modified SWAT to enhance simulation of surface and subsurface flow and nitrate and pesticide transport for landscapes with tile drainage systems and pothole topography.

\section{AnnAGNPS Enhancements}

Recent studies have investigated the use of AnnAGNPS with an ephemeral gully (EG) subroutine. EG erosion has been recognized as significant contributor to sediment losses from agricultural fields, yet most methods for estimating soil erosion do not account for it. The USLE, RUSLE, and MUSLE erosion prediction equations evaluate soil loss as combined sheet and rill erosion, but do not include erosion due to concentrated flow channels, usually referred to as EGs, in their estimates. Watershed models such as AnnAGNPS and SWAT, which are commonly used to evaluate nonpointsource (NPS) pollution in agricultural watersheds, are based only on combined sheet and rill estimates and do not account for EG erosion. Improved accuracy and adequate calibration of watershed models will likely require that EG erosion be considered as a contributor to sediment and nutrient loading to surface water bodies, especially if conservation practices are to be targeted to treat different NPS sources.

Kansas State University is collaborating with the USDAARS and USDA-NRCS on a special emphasis Conservation Effects Assessment Project (CEAP) in the above-mentioned Cheney Lake watershed to study the influence of EG erosion on NPS loading to Cheney Reservoir and to integrate an EG erosion routine into the AnnAGNPS model in order to account for the contribution of EG erosion. Preliminary assessment of soil losses in the Cheney Lake watershed suggest that EG erosion may deliver as much as 50\% of the sediment load to the reservoir. Remote sensing and GIS have been used to quantify the occurrence and extent of EGs in the watershed and to extract gully profiles from a digital elevation model, and soil and engineering properties from NASIS soil data. The Revised Ephemeral Gully Erosion
Model (REGEM) has been incorporated into AnnAGNPS, and an ArcView script and interface have been developed to populate AnnAGNPS with the necessary inputs to assess EG erosion in the watershed.

More accurate and efficient prediction of erosive losses due to ephemeral gullies will allow for better targeting of field management practices and structures to susceptible areas and, thus, control soil erosion and the delivery of sediment and associated nutrients and chemicals to waterways. A comprehensive review of EG erosion research and estimation techniques may be found in Borah et al. (2006).

\section{MODELING Hydrology}

Water transports all the pollutants, including sediment and nutrients, and therefore its accurate prediction is critical and great attention must be given to correctly modeling hydrologic processes. Continuous watershed models (e.g., HSPF and SWAT) consider the entire hydrologic cycle, including precipitation, surface runoff, evapotranspiration, percolation, and return flow from subsurface or groundwater as base flow; therefore, they perform well in long-term continuous simulations, such as yearly, monthly, or daily time intervals. However, they perform poorly during storm events, particularly intense storms (Borah and Bera, 2004) that cause flooding and carry disproportionately large amounts of sediment and nutrients. Therefore, storm event models must be considered in developing TMDLs. Storm event models (e.g., DWSM and KINEROS2) compute primarily rainfall excess and route the excess rainfall over the land surfaces and stream-reservoir network. Some storm event models (e.g., DWSM) simulate subsurface, tile drainage, and base flows as well. Computing rainfall excess and its routing are also major functions of continuous models.

\section{Rainfall Excess}

Many of the continuous and storm event models, such as DWSM, GSSHA, HSPF, KINEROS2, and MIKE SHE, compute rainfall excess rates from rainfall intensities considering initial losses to interception, infiltration, and depression storage and route the excess water over land surfaces to the channels using one of the routing techniques. Some models, such as AGNPS, AnnAGNPS, and SWAT, avoid computing interception and infiltration by using the SCS runoff curve number procedure and compute runoff volumes from rainfall depths, and use empirical relations, such as the Rational formula, to compute peak flows.

DWSM offers an extension of the SCS curve number procedure (Borah, 1989) as an alternative procedure to compute time-varying rainfall excess rates from breakpoint rainfall depths. It performed equivalent to an interception-infiltration based routine (Borah et al., 2002b). Other models may also benefit from this robust procedure whose single parameter, the curve number, has been widely and successfully used for more than half a century.

\section{Flow Routing}

Flow routing is basic to all hydrologic models, although a few of the models, such as the AGNPS, avoid routing flows. Such models typically use the SCS runoff curve number procedure for determining runoff volume and an empirical equation, similar to Rational formula, for peak flow computations. A few other models, such as AnnAGNPS and SWAT, do not route flow over the landscape (overland) but 
rather route flow through the channels using robust but empirical relations. These models can be enhanced with physically based routing schemes.

Many models, such as DWSM, GSSHA, HSPF, KINEROS2, and MIKE SHE, use physically based routing schemes derived from the St. Venant, shallow water wave, or full dynamic equations, governing gradually varied non-steady state flows. These routines and their advantages and disadvantages are extensively discussed in Borah and Bera (2003). Robustness of a model depends heavily on the routing scheme chosen. For example, the analytical solution based kinematic wave routing scheme (Borah, 1989) in DWSM offers a robust routing scheme as well as ease of application due to its single calibration parameter: Manning's roughness coefficient. On the contrary, the numerical solution-based routing schemes of GSSHA, KINEROS2, and MIKE SHE are computationally intensive and less efficient.

A few other models, such as HSPF, apply much simpler versions of the continuity and flow equations with no spatial variation, which may be one of the reasons for their poor performance during intense storms. These models would benefit from advanced flow routing schemes with dynamic features.

\section{Subsurface Flows}

Most of the watershed models simulate subsurface flows. However, their procedures are completely different. Some models, such as MIKE SHE and GSSHA, use computationally intensive numerical schemes. Others, such as HSPF and SWAT, use mostly empirical equations. DWSM uses a lumped, physically based concept. It uses a kinematic storage scheme and an effective lateral saturated hydraulic conductivity $(E L S H C)$ by combining lateral flow, tile drain flow, and base flow. Although ELSHC is a calibration parameter, it carries a physical meaning similar to saturated hydraulic conductivity. Other models may benefit from this or similar simple schemes.

\section{Modeling SEdiment}

Modeling sediment involves computing soil erosion from land surfaces (overland) and stream beds and banks, routing the eroded soil (sediment) over the land surface and through the stream network considering sediment deposition and further erosion due to forces of the flowing water, and predicting sediment discharges and/or sediment yield. Sediment yield is the total amount of sediment generated within a watershed and delivered at its outlet during any given time period. A comprehensive review of existing methodologies for computing watershed sediment yield and sediment modeling is given in Borah et al. (2006).

\section{Land Surface Erosion and Sediment Transport}

Many of the models, such as AGNPS, AnnAGNPS, GWLF, and SWAT, use the USLE or its modifications, MUSLE or RUSLE, to compute land surface erosion. Some of these models (AnnAGNPS and GWLF) use a delivery ratio to compute sediment discharged into a channel or other receiving water body. MUSLE accounts for sediment delivery in SWAT. AGNPS routes sediment over the land surface using a steady-state sediment continuity and effective transport capacity.

Many other models, such as DWSM, GSSHA, HSPF, and KINEROS2, use empirically based splash erosion functions to compute soil erosion due to raindrop impact and route the eroded soil or sediment using a physically based sediment transport capacity concept combined with mass conservation (continuity) equations; this is similar to sediment routing in stream channels, as described below.

\section{Stream Erosion, Deposition, and Sediment Transport}

All of the models route inflowing sediment from land surfaces and upland streams using a physically based sediment transport capacity concept combined with mass conservation (continuity) equations. The models use various sediment transport equations from the literature to compute transport capacities. At every time step, comparisons are made between transport capacity and sediment load (amount of sediment already transported by the water). If the capacity is higher than the load, then there is potential for more erosion from the stream bed and bank. Actual erosion depends on loose soil/sediment available or erosive power of the water and resistance of the stream bed and bank to erosion. If the capacity is lower than the load, there is potential for sediment deposition. Actual deposition depends on flow depth and fall velocities of the suspended sediment particles.

By solving the sediment continuity equation, the models compute sediment discharges and keep track of erosion, deposition, and bed elevation changes. Robustness of a model depends on the solution procedure adopted in solving the continuity equation. For example, the numerical procedure adopted in KINEROS2 is less efficient than the approximate analytical solution adopted in DWSM.

Research must continue in enhancing the models with more physically based routines. Sensitivity analysis and field testing of different sediment transport equations found in the literature must be conducted to find the suitable conditions for their appropriate applications. Only a few such studies, e.g., Alonso et al. (1981), have been conducted; more studies are needed.

None of the models discussed here include stream bank erosion. Stream bank erosion is important; for example, Gianessi et al. (1986) attributed $11 \%$ of total erosion in the U.S. to stream bank erosion. In future research, inclusion of stream bank erosion in models used for TMDLs must be considered. A comprehensive review of stream bank erosion and sediment transport models is given by the ASCE Task Committee on Hydraulics, Bank Mechanics, and Modeling of River Width Adjustment (1998).

\section{Debris Flow}

Streams and rivers naturally carry significant amounts of macroscopic organic debris of the type excluded from standard suspended sediment analyses such as: aquatic vegetation, filamentous and mat algae, wetland (marsh) vegetation, trees, branches, twigs, and leaves. This form of suspended materials is not only important for measurement of suspended solid mass but also for nutrient cycling and oxygen demand. For example, prior to building the levees around the Illinois River, seasonal flooding and storm events would harvest organic debris out of the numerous lakes, pools, bayous, swamps, sloughs, and rich bottomlands along the main stem of the Illinois River. At low flow, much of the main river channel would be choked with decaying vegetation (Krug and Winstanley, 2000). Prior to the levees of the Mississippi and its major tributaries, massive amounts of organic debris were carried by the river system (e.g., Hutchins, 1797; Lyell, 1849; Humphreys and Abbott, 1861; 
Brower, 1893; Dickens, 1966). Indeed, Charles Lyell (known as the father of modern geology) criticized measurements of the Mississippi's sediment load as being underestimates because of the vast amounts of unmeasured organic debris (Riddell, 1846). Today, experience shows that organic debris is important, and this is implicit in limnological classification of streams as being heterotrophic (decomposition exceeds organic production by photosynthesis). None of the existing models have debris flow routines, and future research must be conducted on simulating and including these unavoidable constituents into the models.

\section{Modeling NuTRIENTS}

The principal nutrients simulated by the models are $\mathrm{N}$ and P. For example, SWAT comprehensively models transfers and internal cycling of the major forms of $\mathrm{N}$ and P. SWAT is impressive in that it simulates the $\mathrm{N}$ cycle even more comprehensively than much of the $\mathrm{N}$ cycle literature does, particularly in respect to internal soil cycling (Krug and Winstanley, 2002); thus, weaknesses inherent in modeling $\mathrm{N}$ with specific references to SWAT will be emphasized in the following discussion.

\section{Nitrogen}

SWAT is an especially strong $\mathrm{N}$ model because it is based on the accumulated expertise acquired in agricultural systems, and the bulk of $\mathrm{N}$ studies have been done in agricultural systems. For example, the USDA's 1971 review of nitrate in the environment estimated that 100,000 research experiments had been conducted just on the leaching of nitrate in soil water alone (Viets and Hageman, 1971). SWAT uses this vast background for initialization of three types of soil organic $\mathrm{N}, \mathrm{NH}_{4}-\mathrm{N}$ and $\mathrm{NO}_{3}-\mathrm{N}$, mineralization (decomposition) of organic $\mathrm{N}$ to inorganic $\mathrm{N}$, and immobilization of inorganic $\mathrm{N}$ to organic $\mathrm{N}$. There are modules for nitrification and the amount of $\mathrm{NH}_{3 \text { (gas) }}-\mathrm{N}$ volatilized during nitrification, and various $\mathrm{N}$ gases lost during to microbial reduction of nitrified (e.g., $\mathrm{NO}_{3}-\mathrm{N}$ ) nitrogen. In addition to agronomic $\mathrm{N}$ inputs, SWAT has atmospheric and symbiotic (legumes) $\mathrm{N}$ input modules.

Nevertheless, even the strongest model inherits problems from limiting assumptions employed due to the fact that the $\mathrm{N}$ cycle is poorly understood and that, the more we learn, the more complex the $\mathrm{N}$ cycle is shown to be (Stevenson, 1986; Stevenson and Cole, 1999). Even so, continued research suggests ways that the $\mathrm{N}$ cycle can be defined to improve model results.

Just the top meter of soil is estimated to contain 240,000 million metric tons of N, $90 \%$ of which is in soil humus, whereas human activities are estimated to fix 150 million metric tons of $\mathrm{N}$ per year (Krug and Winstanley, 2002). The soil's store of humus contains such enormous amounts of $\mathrm{N}$ that slight errors in estimated rates of mineralization result in large errors in the amount of nitrate available for plant and microbial uptake, leaching, denitrification, and ammonia/ammonium available for biological microbial uptake and volatilization. The biological and physicochemical processes governing the generation and consumption of inorganic $\mathrm{N}$ are complex and highly heterogeneous in space and time. But this complexity may be simplified by a new soil test that measures only that portion of soil organic $\mathrm{N}$ that will be mineralized (Mulvaney et al., 2006).

Of the Earth's estimated $1.6 \times 10^{17}$ metric tons of $\mathrm{N}$, the geosphere contains 98\%, the atmosphere $2 \%$, and the biosphere, $0.0002 \%$ (Krug and Winstanley, 2002). Nevertheless, since the middle of the 20th century, soil scientists and others have tried to bring the scientific community to consider $\mathrm{N}$-mineral interactions and the geosphere as a potential source of $\mathrm{N}$, even in humid environments (e.g., George and Hastings, 1951; Stevenson, 1959; Graf, 1960; Chalk and Keeney, 1971; Viets and Hageman, 1971; Power et al., 1974; Thomas and Crutchfield, 1974, Brown et al., 1982; Hendry et al., 1984; Thomas et al., 1992; Harker et al., 1997; Fairchild et al., 2000). For example, regarding the effects of limiting assumptions of $\mathrm{N}$ modeling, ammonium- $\mathrm{N}$ is contained in the crystal structure of soil minerals, principally in interlayers of 2:1 clay minerals. This so-called fixed and non-exchangeable $\mathrm{N}$ is assumed to be biologically unavailable. However, appreciable amounts of such crystalstructure $\mathrm{N}$ participate in the $\mathrm{N}$ cycle, interact with $\mathrm{N}$ fertilizer additions, and are available to nitrifying bacteria and plant root systems (Norman et al., 1987; Kuhlmann et al., 1989; Li et al., 1990; Green et al., 1994). For example, the seminal study of Mengel and Scherer (1981) found a net use of $500 \mathrm{~kg} \mathrm{~N}^{-1}$ of such crystal-structure $\mathrm{N}$ during the growing season in the top $90 \mathrm{~cm}$ of loess and alluvial soils under grain crops. Thus, the balance of total $\mathrm{N}$ in the soil-plant system may be improved by removing the limiting assumption that such crystal-structure $\mathrm{N}$ is biologically unavailable and does not participate in $\mathrm{N}$ cycling.

A second limiting assumption is that runoff $\mathrm{N}$ is considered to be dissolved inorganic N (DIN) or particulate organic $\mathrm{N}$ (PON). However, application of urea and anhydrous ammonia solubilize PON to dissolved organic nitrogen (DON) during the weeks to months after application (e.g., Kelly, 1981; Norman et al., 1987), as does tillage of grassland soils (Bhogal et al., 2000). Organic additions also result in DON (Inman et al., 1982; Zsolnay and Gorlitz, 1994; Elrashidi et al., 1999). Furthermore, during the dormant season, stover loses most of its $\mathrm{N}$ to surface runoff (Krug and Winstanley, 2000). As such, as leaves and stalks age, they become progressively more damaged, and the bleeding of nutrients increases markedly (Tukey, 1966). Review shows that the plant material loses its $\mathrm{N}$ principally as DON, and such leaching losses from grasses, legumes, and forbs can average up to $3 / 4$ of total plant $\mathrm{N}$ content lost over the winter (Krug and Winstanley, 2000). Unfortunately, researchers have tightly focused their attention on the leaching of nitrate, thereby missing DON, the principal form of $\mathrm{N}$ leaching from plant and other materials (Thurman, 1986; Northrup et al., 1995; Krug and Winstanley, 2000).

The few studies that have been conducted on conventional cropland soil DON indicate that it is important (e.g., Smith, 1987; Murphy et al., 2000). Furthermore, increasing application of conservation tillage, organic farming, and other nontraditional agronomic practices may be expected to increase the importance of DON in agricultural runoff. DON also needs to be incorporated into watershed models because it is important to the $\mathrm{N}$ cycling of various natural watershed ecosystem components (Timperley et al., 1985; Schoenau and Bettany, 1987; Phipps and Crumpton, 1994; Hedin et al., 
1995; Stepanauskas et al., 1999; Qualls, 2000; Willett et al., 2004).

\section{Phosphorous}

SWAT comprehensively simulates transfers and internal cycling of the major forms of $\mathrm{P}$, very much like it does for $\mathrm{N}$ without gas-phase transitions. The $\mathrm{P}$ cycle is complex, but arguably somewhat less so than $\mathrm{N}$, and appears to be better understood and modeled. Therefore, fewer suggestions for improvement are made here. For example, unlike $\mathrm{N}$, it is widely understood that $\mathrm{P}$ incorporated in soil minerals can be bioavailable and is, accordingly, modeled as such.

On the other hand, like $\mathrm{N}$, soluble $\mathrm{P}$ suffers from the assumption that it is inorganic. Many organic $\mathrm{P}$ compounds released to soil solution are converted to inorganic form by phosphotase-like enzyme activity, which results in underestimation of the role of organic P. Even so, soluble organic P is recognized as being important in many natural ecosystems (e.g., Schoenau and Bettany, 1987; Stevenson and Cole, 1999; Kaiser, 2001; Paytan et al., 2002; Gardolinski et al., 2004), and as referenced above, living and dead biomass leach appreciable proportions of $\mathrm{P}$ in organic form. Review of the literature by Krug and Holinger (2003) shows that beginning with the Rothamsted experiments initiated in the 1840 s, it was recognized that manure additions facilitated the movement of $\mathrm{P}$ down through the soil profile, albeit on a multi-year to multi-decades timescale. Lime and sulfate $\left(\mathrm{SO}_{4}{ }^{2-}\right)$ additions to manures further enhance $\mathrm{P}$ movement, and $\mathrm{SO}_{4}{ }^{2-}$ additions alone enhance movement of $\mathrm{P}$ through soil, albeit on a multi-year to decade timescale. The strong interaction of organic $\mathrm{P}$, inorganic $\mathrm{P}$, and competing physicochemical reactions of $\mathrm{P}$ and other solutes with soil reactive sites are reviewed by Stevenson and Cole (1999) and Krug and Holinger (2003).

\section{ModeLING BMPs}

The primary purpose of many of these models is to be able to predict the impact of future natural or man-made changes, such as case BMPs. Physically based models are the best suitable models for evaluating the impacts of BMP scenarios and changes in climatic or hydrologic conditions on quantities of flow, sediment, and nutrients. All of the models discussed here are able to simulate some BMPs.

A few models, such as REMM and VFSMOD, were developed to simulate specific BMPs: riparian buffers and vegetative filter strips, respectively. APEX is a farm-scale watershed and BMP model that simulates extensive land management strategies. The combination of APEX with SWAT resulted in the SWAPP programming system (Saleh, 2004), which enables one to perform management scenarios, such as multicropping system, at the field and watershed levels. Simulations of these scenarios are extremely important in evaluating BMPs for TMDLs.

More improvements are needed to enable SWAT and other models to reasonably simulate a wider variety of BMPs. Extensive applications and sensitivity analyses are needed to perfect simulations and predictions.

\section{Conclusions}

Models are essential tools for adequate development and implementation of TMDLs. The water quality models with sediment and nutrient components discussed here included loading models (GWLF and PLOAD), receiving water models (AQUATOX, BATHTUB, CE-QUAL-W2, QUAL2E, and QUAL2K), and watershed models having both loading and receiving components (AGNPS, AnnAGNPS, CASC2D/GSSHA, DWSM, HSPF, KINEROS2, LSPC, MIKE SHE, and SWAT). Other models were also discussed regarding components that would be useful in TMDL applications.

The loading models GWLF and PLOAD have both sediment and nutrient load calculation capabilities. The receiving water models AQUATOX, BATHTUB, CEQUAL-W2, QUAL2E, and QUAL2K have nutrient simulation capabilities, among others. Only WASP has both sediment and nutrient simulation capabilities. Among the watershed models, HSPF, LSPC, SWAT, AGNPS, AnnAGNPS, MIKE SHE, DWSM, ANSWERS continuous, SWMM, REMM, and APEX have both sediment and nutrient simulation capabilities, but CASC2D/GSSHA, KINEROS2, ANSWERS storm event, PRMS storm event, WEPP, and VFSMOD have sediment simulation capabilities only.

Some of these models have been used in developing TMDLs, while others have potential for future use. Simple models, such as GWLF and BATHTUB, have been used extensively in some areas for TMDL development because of their ease of use, although they appear to have limitations for use in TMDL implementation. Other models, such as SWAT, have also been used in TMDL development. While SWAT is more labor and data intensive, it offers extensive analysis tools.

Watershed-scale model reviews revealed HSPF, SWAT, and DWSM as promising models for use with sediment and nutrient TMDLs: HSPF for long-term continuous simulations in mixed agricultural and urban watersheds, SWAT for long-term continuous simulations in predominantly agricultural watersheds, and DWSM for storm event simulations in agricultural and suburban watersheds. Combination or combined use of these or other complementary models would benefit in adequate development and implementation of TMDLs. For example, a combination of SWAT and DWSM would result in a more physically based continuous and storm event model with less dependence on empirical parameters.

Combinations of complementary models showed potential for applications with TMDLs. One example is the SWAPP model, which facilitates the simultaneous use of SWAT and APEX to simulate multiple cropping, filter strips, detailed management practices related to farm animal productions, economic impacts of BMPs, and wind erosion.

Robustness or computing efficiencies of models must be considered, along with their accuracies or uncertainties, when selecting a model for TMDL development. For example, the most physically based models (GSSHA, KINEROS2, and MIKE SHE) with numerical solution-based schemes are more computationally intensive and less efficient than DWSM, a model with a similar physically based scheme but using closed-form (analytical) solutions. Special attention must be given to robustness of the hydraulic or hydrologic component, the basic or foundation component for sediment and nutrient simulations. Both efficiency and accuracy are critical for effective uses of modelers' time and resources and successful TMDLs.

Resources should be invested in pursuing and promoting scientifically sound (physically based) and proven robust 
models or techniques, such as the closed-form solution-based kinematic flow routing scheme in DWSM. Other scientifically sound (physically based) models and techniques should be also advanced by making them robust, and simplifying their applications with graphical user interfaces. Several such efforts are in progress with the AnnAGNPS, GWLF, and SWAT models.

A model user must fully understand the background, potentials, and limitations of a model before using it. Example field applications, sensitivity analyses, and full documentation of the models are essential for using these models in the TMDL context. Rigorous education and training with model applications and demonstrations are needed for users to understand the potentials, limitations, and appropriate applications of a model.

Modeling of hydrology and transport of sediment and nutrients has advanced tremendously, but it has not always been consistent with the needs of the TMDL program. Numerous useful models are available today with various capabilities, many of which are applicable or adaptable to TMDL development and implementation. However, benefits to the TMDL program will only accrue when future advances, made by making the best use of existing models, enhancing the existing models, and developing new models or supplemental components, are undertaken with consideration of their application for TMDL development and implementation.

\section{ACKNOWLEDGEMENTS}

This article is the one of a series of articles developed by members of the USDA-CSREES Regional Project S-1004 "Development and Evaluation of TMDL Planning and Assessment Tools and Processes" and the ASABE SW-21 Hydrology Committee. The authors would like to acknowledge the editorial leadership and coordination provided by Rafael Muñoz-Carpena, Adel Shirmohammadi, and George Vellidis in this group effort. The article is partly supported by affiliated institutions of the authors, with special acknowledgements to Borah Hydro-Environmental Modeling and Kansas State University. The authors also acknowledge the other members of the group and two anonymous peer reviewers for reviewing and editing the manuscript and providing useful comments and helpful suggestions.

\section{REFERENCES}

Alonso, C. V., W. H. Neibling, and G. R. Foster. 1981. Estimating sediment transport capacity in watershed modeling. Trans. ASAE 24(5): 1211-1220, 1226.

ASCE Task Committee on Hydraulics, Bank Mechanics, and Modeling of River Width Adjustment. 1998. River width adjustment. II: Modeling. J. Hydraulic Eng. ASCE 124(9): 903-917.

Beasley, D. B., L. F. Huggins, and E. J. Monke. 1980. ANSWERS: A model for watershed planning. Trans. ASAE 23(4): 938-944.

Benham, B. L., C. Baffaut, R. W. Zeckoski, Y. A. Pachepsky, K. R. Mankin, A. M. Sadeghi, K. M. Brannan, M. L. Soupir, and M. J. Habersack. 2006. Modeling bacteria fate and transport in watersheds to support TMDLs. Trans. ASABE 49(4): 987-1002.

Bhogal, A., D. V. Murphy, S. Fortune, M. A. Shepherd, D. J. Hatch, S. C. Jarvis, J. L. Gaunt, and K. W. T. Gouylding. 2000. Distribution of nitrogen pools in the soil profile of undisturbed and reseeded grasslands. Biol. Fert. Soils 30(4): 356-363.
Bhuyan, S. J., L. Marzen, J, K. Koelliker, J. A. Harrington, and P. L. Barnes. 2002a. Assessment of runoff and sediment yield using remote sensing, GIS, and AGNPS. J. Soil and Water Conservation 57(6): 351-364.

Bhuyan, S. J., K. Mankin, J. M. S. Hutchinson, D. G. Goodin, and J. K. Koelliker. 2002b. Deriving land-cover map of a large agricultural watershed from multi-temporal Landsat scenes. $J$. Environ. Hydrology Volume 10, Paper 6. San Antonio, Texas: International Association of Environmental Hydrology. Available at: www.hydroweb.com. Accessed 10 January 2006.

Bhuyan, S. J., K. R. Mankin, and J. K. Koelliker. 2003a. Watershed-scale antecedent moisture content selection for hydrologic modeling. Trans. ASAE 46(2): 303-310.

Bhuyan, S. J., J. K. Koelliker, L. Marzen, and J. A. Harrington. 2003b. An integrated approach for water quality assessment of a Kansas watershed. Environ. Modelling and Software 18(5): 473-484.

Bicknell, B. R., J. C. Imhoff, J. L. Kittle Jr., T. H. Jobes, and A. S. Donigian, Jr. 2001. Hydrological Simulation Program Fortran: HSPF Version 12 User's Manual. Athens, Ga.: U.S. Environmental Protection Agency. Available at: www.epa.gov/waterscience/basins/bsnsdocs.html\#hspf. Accessed 3 January 2006.

Bingner, R. L., and F. D. Theurer. 2001. AnnAGNPS Technical Processes: Documentation Version 2. Unpublished report. Oxford, Miss.: USDA-ARS National Sedimentation Laboratory.

Borah, D. K. 1989. Runoff simulation model for small watersheds. Trans. ASAE 32(3): 881-886.

Borah, D. K., and M. Bera. 2003. Watershed-scale hydrologic and nonpoint-source pollution models: Review of mathematical bases. Trans. ASAE 46(6): 1553-1566.

Borah, D. K., and M. Bera. 2004. Watershed-scale hydrologic and nonpoint-source pollution models: Review of applications. Trans. ASAE 47(3): 789-803.

Borah, D. K., M. Demissie, and L. Keefer. 2002a. AGNPS-based assessment of the impact of BMPs on nitrate-nitrogen discharging into an Illinois water supply lake. Water International 27(2): 255-265.

Borah, D. K., R. Xia, and M. Bera. 2002b. Chapter 5: DWSM - A dynamic watershed simulation model. In Mathematical Models of Small Watershed Hydrology and Applications, 113-166. V. P. Singh and D. K. Frevert, eds. Highlands Ranch, Colo.: Water Resources Publications.

Borah, D. K., M. Bera, and R. Xia. 2004. Storm event flow and sediment simulations in agricultural watersheds using DWSM. Trans. ASAE 47(5): 1539-1559.

Borah, D. K., E. C. Krug, M. Bera, X.-Z. Liang, and J. G. Arnold. 2005. Storm event and continuous modeling of an Illinois watershed to evaluate surface water supplies. ASAE Paper No. 052153. St. Joseph, Mich.: ASABE.

Borah, D. K., E. C. Krug, and D. Yoder. 2006. Chapter 17: Watershed sediment yield. In ASCE Manual 110, Sedimentation Engineering: Theory, Measurements, Modeling, and Practice. M. H. Garcia, ed. Reston, Va.: ASCE Environmental and Water Resources Institute (to be released August 2006).

Bosch, D. J., C. Ogg, E. Osei, and A. Stoecker. 2006. Economic models for TMDL assessment and implementation. Trans. $A S A B E$ 49(4): 1051-1065.

Bouraoui, F., I. Braud, and T. A. Dillaha. 2002. Chapter 22: ANSWERS: A nonpoint-source pollution model for water, sediment, and nutrient losses. In Mathematical Models of Small Watershed Hydrology and Applications, 833-882. V. P. Singh and D. K. Frevert, eds. Highlands Ranch, Colo.: Water Resources Publications.

Brower, J. V. 1893. The Mississippi and Its Sources. Minneapolis, Minn.: Harrisson and Smith, State Printers.

Brown, P. L., A. D. Halvorson, F. H. Mayland, and M. R. Miller. 1982. Saline-seep diagnosis, control, and reclamation. 
Conservation Research Report No. 30. Washington, D.C.: USDA.

Brown, L. C., and T. O. Barnwell, Jr. 1987. The enhanced water quality models QUAL2E and QUAL2E-UNCAS documentation and user manual. EPA document EOA/600/3-87/007. Athens, Ga.: USEPA.

Chalk, P. M., and D. R. Keeney. 1971. Nitrate and ammonium contents of Wisconsin limestones. Nature 229(5279): 42.

Chapra, S. C., and G. J. Pelletier. 2003. QUAL2K: A Modeling Framework for Simulating River and Stream Water Quality: Documentation and User's Manual. Medford, Mass.: Tufts University, Department of Civil and Environmental Engineering.

Cole, T. M., and E. M. Buchak. 1995. CE-QUAL-W2: A Two-Dimensional, Laterally Averaged Hydrodynamic and Water Quality Model, Version 2.0. Instruction Report EL-95-1. Vicksburg, Miss.: U.S. Army Engineer Waterways Experiment Station.

Cole, T. M., and S. A. Wells. 2003. CE-QUAL-W2: A Two-Dimensional, Laterally Averaged Hydrodynamic and Water Quality Model, Version 3.1. Instruction Report EL-03-1. Vicksburg, Miss.: U.S. Army Engineering and Research Development Center.

Dickens C. 1966 (reprinted). American Notes and Pictures from Italy. Oxford, U.K.: Oxford University Press.

Downer, C. W., and F. L. Ogden. 2002. GSSHA User's Manual: Gridded Surface Subsurface Hydrologic Analysis, Version 1.43 for WMS 6.1. ERDC Technical Report. Vicksburg, Miss.: Engineering Research and Development Center.

Du, B., J. G. Arnold, A. Saleh, and D. B. Jaynes. 2005. Development and application of SWAT to landscape with tiles and potholes. Trans. ASAE 48(3): 1121-1133.

Easterling, N. 2000. Future growth projections for the Lake Waco/Bosque River watershed. WP005. Stephenville, Texas: Texas Institute for Applied Environmental Research, Tarleton State University.

Elrashidi, M. A., V. C. Baligar, R. F. Korcak, N. Persaud, and K. D. Ritchey. 1999. Chemical composition of leachate of dairy manure mixed with fluidized bed combustion residue. $J$. Environ. Qual. 28(4): 1243-1251.

Evans, B. M., S. A. Sheeder, K. J. Corradini, and W. S. Brown. 2001. AVGWLF Version 3.2. User's Guide. Harrisburg, Pa.: Environmental Resources Research Institute, Pennsylvania State University and Pennsylvania Department of Environmental Protection, Bureau of Watershed Conservation.

Evans, B. M., S. A. Sheeder, and D. W. Lehning. 2003. A spatial technique for estimating streambank erosion based on watershed characteristics. J. Spatial Hydrology 3(1). Available at: www.spatialhydrology.com/journal/paper/erosion/erosion.pdf.

Fairchild, G. L., D. A. J. Barry, M. J. Goss, A. S. Hamill, P. Lafrance, P. H. Milburn, R. R. Simard, and B. J. Zebart. 2000. Groundwater quality. In The Health of Our Water: Toward Sustainable Agriculture in Canada, 61-73. D. R. Coote and L. J. Gregorich, eds. Pub. 2020/E. Ottawa, Ontario: Agriculture and Agri-Food Canada.

Flanagan, D. C., and M. A. Nearing, eds. 1995. USDA Water Erosion Prediction Project: Technical Documentation. NSERL Report No. 10. West Lafayette, Ind.: USDA-ARS National Soil Erosion Research Laboratory.

Flowers, J. D., C. Santhi, L. M. Hauck, and R. L. Kiesling. 2000. The use of an integrated modeling approach for TMDL development in the Lake Waco/Bosque River watershed. ASAE Paper No. 002212. St. Joseph, Mich.: ASAE.

Flowers, J., L. Hauck, and R. Kiesling. 2001. Water quality modeling of Lake Waco using CE-QUALW2 for the assessment of phosphorus control strategies. TR0114. Stephenville, Texas: Texas Institute for Applied Environmental Research, Tarleton State University.
Gardolinski, P. C.F. C., P. J. Worsfold, and I. D. McKelvie. 2004. Seawater-induced release and transformation of organic and inorganic phosphorus from river sediments. Water Res. 38(3): 688-692.

George, W. O., and W. W. Hastings. 1951. Nitrate in the ground water of Texas. EOS Trans. American Geophys. Union 32(3): 450-456.

Gianessi L. P., H. M. Peskin, P. Crosson, and C. Puffer. 1986. Nonpoint-source pollution: Are cropland controls the answer? $J$. Soil and Water Conserv. 41(4): 215-218.

Graf, D. L. 1960. Part II: Sedimentary carbonate rocks. In Geochemistry of Carbonate Sediments and Sedimentary Carbonate Rocks. Circular No. 298. Urbana, Ill.: Illinois State Geological Survey.

Green, W. H., and G. A. Ampt. 1911. Studies on soil physics: 1. The flow of air and water through soils. J. Agric. Sci. 4: 11-24.

Green, C. J., A. M. Blackmer, and N. C. Yang. 1994. Release of fixed ammonium during nitrification in soils. SSSA J. 58(5): 1411-1415.

Haith, D. A., and L. L. Shoemaker. 1987. Generalized watershed loading functions for stream flow nutrients. Water Res. Bull. 23(3): 471-478.

Haith, D. A., R. Mandel, and R. S. Wu. 1992. GWLF (Generalized Watershed Loading Functions): Version 2.0. User's Manual. Ithaca, N.Y.: Cornell University, Department of Agricultural and Biological Engineering.

Harker, D. B., K. Bolton, L. Townley-Smith, and B. Bristol. 1997. A Prairie-Wide Perspective of Nonpoint Agricultural Effects on Water Quality. Regina, Saskatchewan: Agriculture and Agri-Food Canada.

Hedin, L. O., J. J. Armesto, and A. H. Johnson. 1995. Patterns of nutrient loss from unpolluted, old-growth temperate forests: Evaluation of biogeochemical theory. Ecol. 76(2): 493-509.

Hendry, M. J., R. G. L. McCready, and W. D. Gould. 1984. Distribution, source, and evolution of nitrate in a glacial till of southern Alberta, Canada. J. Hydrol. 70: 117-198.

Houser, J. B., A. Saleh, and L. M. Hauck. 2004. Development and Validation of Dynamic Fertilizer Model. Technical Report TR0410. Stephenville, Texas: Texas Institute for Applied Environmental Research, Tarleton State University.

Huber, W. C., and R. E. Dickinson. 1988. Storm Water Management Model User's Manual Version 4. Report No. EPA/600/3-88/001a. Athens, Ga.: U.S. EPA Environmental Research Laboratory.

Humphreys, A. A., and H. L. Abbot. 1861. Report Upon the Physics and Hydraulics of the Mississippi River. Philadelphia, Pa.: J. B. Lippincott.

Hutchins, T. 1797. Appendix No. 1: An historical narrative and topographic description of Louisiana, and West-Florida. In $A$ Topographic Description of the Western Territory of North America, 388-485. 3rd ed. G. Imlay, ed. Reprinted Series in American Studies, 1968. St. Paul, Minn.: University of Minnesota.

IEPA. 2003. Charleston side channel reservoir total maximum daily load report. IEPA/BOW/03-013. Springfield, Ill.: Illinois Environmental Protection Agency, Bureau of Water.

IEPA. 2004. Altamont new reservoir TMDL report. IEPA/BOW/03-011. Springfield, Ill.: Illinois Environmental Protection Agency, Bureau of Water.

IEPA. 2006. Total maximum daily load: TMDL report info. Springfield, Ill.: Illinois Environmental Protection Agency. Available at: www.epa.state.il.us/water/tmdl/tmdl-reports.html. Accessed 9 February 2006.

Inman, J. C., M. S. McIntosh, J. E. Foss, and D. C. Wolf. 1982. Nitrogen and phosphorus movement in compost-amended soils. J. Environ. Qual. 11(3): 529-532.

Jones, C. A. 1983. A survey of the variability in tissue nitrogen and phosphorus concentrations in maize and grain sorghum. Field Crops Res. 6: 133-147. 
Kaiser, K. 2001. Dissolved organic phosphorus and sulphur as influenced by sorptive interactions with mineral subsoil horizons. European J. Soil Sci. 52(3): 489-493.

Kalin, L., and M. M. Hantush. 2003. Evaluation of sediment transport models and comparative application of two watershed models. EPA/600/R-03/139. Cincinnati, Ohio: USEPA, National Risk Management Research Laboratory.

Kelly, J. M. 1981. Carbon flux to surface mineral soil after nitrogen and phosphorus fertilization. SSSA. J. 45(3): 669-670.

Koelliker, J. K., and C. E. Humbert. 1989. Applicability of AGNPS model for water quality planning. ASAE Paper No. 892042. St Joseph, Mich.: ASAE.

Krug, E. C., and D. Winstanley. 2000. A contribution to the characterization of Illinois reference/background conditions for setting nitrogen criteria for surface waters in Illinois. ISWS Contract Report 2000-08. Champaign, Ill.: Illinois State Water Survey.

Krug, E. C., and D. Winstanley. 2002. The need for comprehensive and consistent treatment of the nitrogen cycle and mass balance studies: I. Terrestrial nitrogen cycle. Sci. Tot. Environ. 293: 1-29.

Krug, E. C., and S. E. Holinger. 2003. Identification of factors that aid carbon sequestration in Illinois agricultural systems. ISWS Contract Report 2003-02. Champaign, Ill.: Illinois State Water Survey.

Kuhlmann, H., P. B. Barraclough, and A. H. Weir. 1989. Utilization of mineral nitrogen in the subsoil by winter wheat. $Z$. Pflanzenernahr. Bodenk. 152: 291-295.

Leavesley, G. H., and L. G. Stannard. 1995. Chapter 9: The precipitation-runoff modeling system - PRMS. In Computer Models of Watershed Hydrology, 281-310. V. P. Singh, ed. Highlands Ranch, Colo.: Water Resources Publications.

Li, C., X. Fan, and K. Mengel. 1990. Turnover of interlayer ammonium in loess-derived soil grown with winter wheat in the Shaanxi Province of China. Biol. Fert. Soils 9(3): 211-214.

Linsley, R. K., M. A. Kohler, and J. L. H. Paulhus. 1958. Hydrology for Engineers. New York, N.Y.: McGraw-Hill.

Lyell, C. 1849. A Second Visit to the United States of North America. Vol. II. London, U.K.: John Murray.

Marzen, L., S. J. Bhuyan, J. A. Harrington, and J. K. Koelliker. 2000. Water quality modeling in the Red Rock Creek watershed. In Proc. Applied Geography Conferences 23: 175-182. Binghampton, N.Y.: SUNY Binghamton.

McElroy, A. D., S. Y. Chiu, and J. W. Nebgen. 1976. Loading functions for assessment of water pollution from nonpoint sources. EOA document EPA 600/2-76-151. Athens, Ga.: USEPA.

Mengel, K., and H. W. Scherer. 1981. Release of nonexchangeable (fixed) soil ammonium under field conditions during the growing season. Soil Sci. 131(4): 226-232.

Milligan, C. R., and L. M. Pope. 2001. Occurrence of phosphorus, nitrate, and suspended solids in streams of the Cheney Lake watershed, south-central Kansas, 1997-2000. USGS Water-Resources Investigations Report 01-4199. Reston, Va.: USGS.

Mulvaney, R. L., S. A. Khan, and T. R. Ellsworth. 2006. Need for a soil-based approach in managing nitrogen fertilizers for profitable corn production. SSSA J. 70(1): 172-182.

Muñoz-Carpena, R., J. E. Parsons, and J. W. Gilliam. 1999. Modeling hydrology and sediment transport in vegetative filter strips and riparian areas. J. Hydrology 214(1-4): 111-129.

Muñoz-Carpena, R., R. G. Vellidis, A. Shirmohammadi, and W. W. Wallender. 2006. Evaluation of modeling tools for TMDL development and implementation. Trans. ASABE 49(4): 961-965.

Murphy, D. V., A. J. Macdonald, E. A. Stockdale, K. W. T. Goulding, S. Fortune, J. L. Gaunt, P. R. Poulton, J. A. Wakefield, C. P. Webster, and W. S. Wilmer. 2000. Soluble organic nitrogen in agricultural soils. Biol. Fert. Soils 30(5-6): 374-387.
Neitsch, S. L., J. G. Arnold, J. R. Kiniry, R. Srinivasan, and J. R. Williams. 2002. Soil and Water Assessment Tool User's Manual Version 2000. GSWRL Report 02-02, BRC Report 02-06, TR-192. College Station, Texas: Texas Water ResourcesInstitute, Texas A\&M University. Available at: www.epa.gov/waterscience/basins/bsnsdocs.html\#swat. Accessed 3 January 2006.

Norman, R. J., L. T. Kurtz, and F. J. Stevenson. 1987. Solubilization of soil organic matter by liquid anhydrous ammonia. SSSA J. 51(3): 809-812.

Northrup, R. R., Z. Yu, R. A. Dahlgren, and K. A. Vogt. 1995. Polyphenol control of nitrogen release from pine litter. Nature 377(6546): 227-229.

Ogden, F. L., and P. Y. Julien. 2002. Chapter 4: CASC2D: A two-dimensional, physically based, Hortonian hydrologic model. In Mathematical Models of Small Watershed Hydrology and Applications, 69-112. V. P. Singh and D. K. Frevert, eds. Highlands Ranch, Colo.: Water Resources Publications.

Paytan, A., Y. Kolodny, A. Neori, and B. Luz. 2002. Rapid biologically mediated oxygen isotope exchange between water and phosphate. Global Biogeochem. Cycl. 16(1): Article No. $2001 G B 001430$.

Penn State. 2006. AVGWLF. University Park, Pa.: Penn State Institutes of the Environment. Available at: www.avgwlf.psu.edu/. Accessed 9 February 2006.

Phipps, R. G., and W. G. Crumpton. 1994. Factors affecting nitrogen loss from experimental wetlands with different hydrologic loads. Ecol. Eng. 3(4): 399-408.

Pope, L. M. 2002. Significant findings of water-quality studies and implications for Cheney Lake watershed, south-central Kansas, 1996-2001. USGS Fact Sheet 009-02. Reston, Va.: USGS.

Pope, L. M., and V. G. Christensen. 1997. Water-quality study of the Cheney Lake watershed, south-central Kansas. USGS Fact Sheet 104-97. Reston, Va.: USGS.

Power, J. F., J. J. Bond, F. M. Sandoval, and W. O. Wilis. 1974. Nitrification in paleocene shale. Science 183(4129): 1077-1079.

Qualls, R. G. 2000. Comparison of the behavior of soluble organic and inorganic nutrients in forest soils. For. Ecol. Manage. 138: 29-50.

Refsgaard, J. C., and B. Storm. 1995. Chapter 23: MIKE SHE. In Computer Models of Watershed Hydrology, 809-846. V. P. Singh, ed. Highlands Ranch, Colo.: Water Resources Publication.

Renard, K. G., G. R. Foster, G. A. Weesies, D. K. McCool, and D. C. Yoder, coordinators. 1997. Predicting soil erosion by water: A guide to conservation planning with the Revised Universal Soil Loss Equation (RUSLE). Agriculture Handbook No. 703. Washington, D.C.: USDA Agricultural Research Service.

Riddell, J. L. 1846. Deposits of the Mississippi River and changes at its mouth. Commercial Rev. South and West 49: 433-439.

Rosenthal, W. D., and D. W. Hoffman. 1999. Hydrologic modeling/GIS as an aid in locating monitoring sites. Trans. ASAE 42(6): 1591-1598.

Rosenthal, W. D., W. L. Harman, E. Wang, and B. Sheng. 2001. Arroyo Colorado River sedimentation: An investigation of range and cropland management practices to reduce erosion. Report No. 01-32. Temple, Texas: Blackland Research Center.

Saleh, A. 2004. Application of SWAT and APEX models using SWAPP (SWAT/APEX Program) for Upper North Bosque River watershed in Texas. ASAE Paper No. 042103. St. Joseph, Mich.: ASAE.

Saleh, A., and B. Du. 2004. Evaluation of SWAT and HSPF within BASINS program for the Upper North Bosque River watershed in central Texas. Trans. ASAE 47(4): 1039-1049.

Saleh, A., J. G. Arnold, P. W. Gassman, L. M. Hauck, W. D. Rosenthal, J. R. Williams, and A. M. S. McFarland. 2000. Application of SWAT for the Upper North Bosque River watershed. Trans. ASAE 43(5): 1077-1087. 
Santhi, C., J. R. Williams, and W. A. Dugas. 2001a. Water quality modeling of the Bosque River watershed for the assessment of phosphorus control strategies. BRC Report No. 01-34. Temple, Texas: Texas Agricultural Experiment Station, Blackland Research and Extension Center.

Santhi, C., J. G. Arnold, J. R. Williams, W. A. Dugas, R. Srinivasan, and L. M. Hauck. 2001b. Validation of the SWAT model on a large river basin with point and nonpoint sources. J. American Water Res. Assoc. 37(5): 1169-1188.

Schoenau, J. J., and J. R. Bettany. 1987. Organic matter leaching as a component of carbon, nitrogen, phosphorus, and sulfur cycles in a forest, grassland, and gleyed soil. SSSA J. 51(3): 646-651.

SCS. 1972. Section 4: Hydrology. In National Engineering Handbook. Washington, D.C.: USDA Soil Conservation Service.

SCS. 1983. Chapter 19, Section 4: Hydrology. In National Engineering Handbook. Washington, D.C.: USDA Soil Conservation Service.

Shirmohammadi, A., I. Chaubey, R. D. Harmel, D. D. Bosch, R. Muñoz-Carpena, C. Dharmasri, A. Sexton, M. Arabi, M. L. Wolfe, J. Frankenberger, C. Graff, and T. M. Sohrabi. 2006. Uncertainty in TMDL models. Trans. ASABE 49(4): 1033-1049.

Shoemaker, L., T. Dai, J. Koenig, and M. Hantush. 2005. TMDL model evaluation and research needs. EPA/600/R-05/149. Cincinnati, Ohio: U.S. EPA, National Risk Management Research Laboratory. Available at: www.epa.gov/ORD/NRMRL/pubs/600r05149/600r05149.pdf. Accessed 28 December 2005.

Singh, V. P., ed. 1995. Computer Models of Watershed Hydrology. Highlands Ranch, Colo.: Water Resources Publications.

Singh, V. P., and D. K. Frevert, eds. 2002a. Mathematical Models of Large Watershed Hydrology. Highlands Ranch, Colo.: Water Resources Publications.

Singh, V. P., and D. K. Frevert, eds. 2002b. Mathematical Models of Small Watershed Hydrology and Applications. Highlands Ranch, Colo.: Water Resources Publications.

Singh, V. P., and D. K. Frevert, eds. 2006. Watershed Models. Boca Raton, Fla.: CRC Taylor and Francis.

Smith, R. E., D. C. Goodrich, D. A. Woolhiser, and C. L. Unkrich. 1995. Chapter 20: KINEROS - A kinematic runoff and erosion model. In Computer Models of Watershed Hydrology, 697-732. V. P. Singh, ed. Highlands Ranch, Colo.: Water Resources Publications.

Smith, S. J. 1987. Soluble organic nitrogen losses associated with recovery of mineralized nitrogen. SSSA J. 51(5): 1191-1194.

Stepanauskas, R., L. Leonardson, and L. J. Tranvik. 1999. Bioavailability of wetland-derived DON to freshwater and marine bacterioplankton. Limnol. Oceanogr. 44(6): 1477-1485.

Stevenson, F. J. 1959. On the presence of fixed ammonium in rocks. Science 130(3369): 221-222.

Stevenson, F. J. 1986. Cycles of Soil: Carbon, Nitrogen, Phosphorus, Micronutrients. New York, N.Y.: Wiley Interscience.

Stevenson, F. J., and M. A. Cole. 1999. Cycles of Soil: Carbon, Nitrogen, Phosphorus, Micronutrients. 2nd ed. New York, N.Y.: Wiley Interscience.

Tetra Tech, Inc., and USEPA. 2002. The LSPC Watershed Modeling System: Users' Manual. Athens, Ga.: U.S. Environmental Protection Agency. Available at: www.epa.gov/athens/wwqtsc/html/lspc.html. Accessed 4 January 2006.

Thomas, G. W., and J. D. Crutchfield. 1974. Nitrate-nitrogen and phosphorus contents of streams draining small agricultural watersheds in Kentucky. J. Environ. Qual. 3(1): 46-49.

Thomas, G. W., G. R. Hasler, and J. D. Crutchfield. 1992. Nitrate-nitrogen and phosphate-phosphorus in seven Kentucky streams draining small agricultural watersheds: Eighteen years later. J. Environ. Qual. 21(1): 147-150.
Thurman, E. M. 1986. Organic Geochemistry of Natural Waters. Dordrecht, The Netherlands: Martinus Nijhoff/Dr W. Junk Publishers.

Timperley, M. H., R. J. Vigor-Brown, M. Kawashima, and M. Ishigami. 1985. Organic nitrogen compounds in atmospheric precipitation: their chemistry and availability to phytoplankton. Canadian J. Fish. Aquatic Sci. 42(6): 1171-1177.

Tukey, H. B., Jr. 1966. Leaching of metabolites from above-ground plant parts and its implications. Bull. Torrey Bot. Club 93: 385-401.

USEPA. 1995. QUAL2E Windows Interface User's Guide. EPA/823/B/95/003. Washington, D.C.: U.S. Environmental Protection Agency.

USEPA. 2001. Better Assessment Science Integrating Point and Nonpoint Sources: BASINS Version 3.0 User's Manual. EPA-823-B-01-001. Washington, D.C.: Office of Water, U.S. Environmental Protection Agency. Available at: www.epa.gov/waterscience/basins/b3webdwn.htm. Accessed 3 January 2006.

USEPA. 2004. Users Manual for AQUATOX (Release 2): Modeling Environmental Fate and Ecological Effects in Aquatic Ecosystems Volume 1. EPA-823-B-04-001. Washington, D.C.: U.S. Environmental Protection Agency, Office of Water.

USEPA. 2006. Total Maximum Daily Loads: National section 303(d) list fact sheet. Washington, D.C.: U.S. Environmental Protection Agency. Available at: http://oaspub.epa.gov/waters/national_rept.control . Accessed 9 February 2006.

Vellidis, G., P. Barnes, D. D. Bosch, and A. M. Cathey. 2006. Mathematical simulation tools for developing dissolved oxygen TMDLs. Trans. ASABE 49(4): 1003-1022.

Viets, F. G., Jr., and R. H. Hageman. 1971. Factors Affecting the Accumulation of Nitrate in Soil, Water, and Plants. Agriculture Handbook 413. Washington, D.C.: U.S. Government Printing Office.

Walker, W. W. 1986. Empirical Methods for Predicting Eutrophication in Impoundments; Report 3, Phase III: Applications Manual. Technical Report E-81-9. Vicksburg, Miss.: U.S. Army Engineers Waterways Experiment Station.

Willett, V. B., J. J. Green, A. J. MacDonald, J. A. Baddeley, G. Cadish, S. M. J. Francis, K. W. T. Goulding, G. Saunders, E. A. Stockdale, C. A., Watson, and D. L. Jones. 2004. Impact of land use on soluble organic nitrogen in soil. Water Air Soil Pollut.: Focus 4(6): 53-60.

Williams, J. R. 1969. Flood routing with variable travel time or variable storage coefficients. Trans. ASAE 12(1): 100-103.

Williams, J. R. 1975. Sediment routing for agricultural watersheds. Water Res. Bull. 11(5): 965-974.

Williams, J. R. 1980. SPNM, a model for predicting sediment, phosphorus, and nitrogen yields from agricultural basins. Water Res. Bull. 16(5): 843-848.

Williams, J. R. 1995. Chapter 25: The EPIC model. In Computer Models of Watershed Hydrology, 909-1000. V. P. Singh, ed. Highlands Ranch, Colo.: Water Resources Publications.

Williams, J. R., and R. W. Hann. 1978. Optimal operation of large agricultural watersheds with water quality constraints. Technical Report No. 96. College Station, Texas: Texas A\&M University, Texas Water Resources Institute.

Williams, J. R., and R. C. Izaurralde. 2006. Chapter 18: The APEX model. In Watershed Models, 437-482. V. P. Singh and D. K. Frevert, eds. New York, N.Y.: CRC Taylor and Francis.

Williams, J. R, J. G. Arnold, and R. Srinivasan. 2000. The APEX model. BRC Report No. 00-06. Temple, Texas: Blackland Research Center.

Wischmeier, W. H., and D. D. Smith. 1978. Predicting Rainfall-Erosion Losses: A Guide to Conservation Planning. Agriculture Handbook No. 537. Washington, D.C.: USDA Agricultural Research Service. 
Woolhiser, D. A., R. E. Smith, and D. C. Goodrich. 1990. KINEROS, A Kinematic Runoff and Erosion Model: Documentation and User Manual. ARS-77. Fort Collins, Colo.: USDA Agricultural Research Service.

Yagow, G. 2004. Using GWLF for development of "reference watershed approach" TMDLs. ASAE Paper No. 042262. St. Joseph, Mich.: ASAE.

Yagow, G., B. Wilson, P. Srivastava, and C. C. Obropta. 2006. Use of biological indicators in TMDL assessment and implementation. Trans. ASABE 49(4): 1023-1032.
Young, R. A., C. A. Onstad, D. D. Bosch, and W. P. Anderson. 1987. AGNPS, Agricultural nonpoint source pollution model: A watershed analytical tool. Conservation Research Report 35. Washington, D.C.: USDA.

Zsolnay, A., and H. Gorlitz. 1994. Water-extractable organic matter in arable soils: Effects of drought and long-term fertilization. Soil Biol. Biochem. 26(9): 1257-1261. 